\title{
The Effects of the 1986 and 1993 Tax Reforms on Self-Employment
}

\author{
Kevin Moore*
}

December 22, 2003

\begin{abstract}
This paper adds a new dimension to the literature that uses individual level data to assess the effects of tax policy on self-employment. Specifically, this study uses repeated cross-section data from the Surveys of Consumer Finances (SCF) against the background of the tax reforms of 1986 and 1993 to gauge the influence of taxes on self-employment. Using the 1986 and 1993 tax rate reforms as natural experiments allows for the identification of the effect of taxes on the choice to become self-employed. The findings of this paper indicate that marginal and average tax rates are negatively related to the propensity to become self-employed. However, these effects are only significant for the 1986 tax reforms and are sensitive to the model specification. Other factors, such as education, industry, wealth, and attitude toward risks, are consistently more important influences on the choice to become self-employed.
\end{abstract}

*Board of Governors of the Federal Reserve System, Washington, DC, Kevin.B.Moore@frb.gov. The author would like to thank Robert Avery, Ana Azicorbe, Reagan Baughman, Don Bruce, Chris Carroll, Arthur Kennickell, Robert Moffitt, Nicole Nestoriak, Karen Pence, Matt Shum, Martha Starr, and participants at the Federal Reserve Lunch Workshop, the 2002 National Tax Association Annual meetings, the UMD-JHU Joint Applied Micro Workshop, and the JHU Applied Micro Workshop. Special thanks go to Dan Feenberg and the NBER for allowing the author to use the TAXSIM program. All opinions expressed in this paper are those of the author alone and do not necessarily reflect those of the Board of Governors of the Federal Reserve System. All errors are the responsibility of the author. 


\section{Introduction}

The entrepreneur has always been a key figure in capitalist economic theory. While seeking profit the entrepreneur may foster competition in the economy, introduce new ideas and technology, and possibly create new jobs. These predicted positive effects of entrepreneurship have sparked policy interest in promoting entrepreneurship, with the key issues being how to encourage individuals to become entrepreneurs and what policy tools work best to achieve this end. ${ }^{1}$

One policy tool that many have championed is tax policy. As with everyone else in the economy, entrepreneurs are affected by the government's tax policies. However, entrepreneurs may be affected differently than those who work for someone else, because of variations in the tax laws with respect to the two groups, or because of individual differences between entrepreneurs and employees. There are many links between entrepreneurship (self-employment) and taxation. In general, the self-employed have more flexibility in reporting taxes, and may be more sensitive to tax policy. There are efficiency concerns if the tax system is encouraging people to become self-employed for the wrong reasons, say to undertake tax evasion, or if high tax rates discourage individuals who would be highly productive entrepreneurs. Furthermore, if the expected returns to success accrue more directly to the self-employed than employees, the progressive structure of the tax system could be more of an issue for the self-employed. ${ }^{2}$

Of course, there are many more interactions between taxation and self-employment, but for the purposes of this paper, we will focus on how a change in marginal or average tax rates affects the propensity to become self-employed. Specifically, this is the first study to use repeated cross-section data (RCS) from the 1983, 1989, 1992, 1995, 1998, and 2001 Surveys of Consumer Finances (SCF) against the background of the tax reforms of 1986 and 1993 to gauge the influence of taxes on self-employment. Using the 1986 and 1993 tax rate reforms as natural experiments allows for the identification of the effect of taxes on the choice to become selfemployed. Due to the richness of the SCF data, we are able to control for many of the factors that influence the decision to become self-employed (such as household wealth) and to compute marginal and average tax rates using the SCF data and the NBER TAXSIM program.

There is a fairly large existing literature of empirical studies of self-employment and taxation. The majority of these studies, such as Long (1982a, 1982b), Moore (1983), Blau (1987), Parker (1996), and Schuetze (1998), find that higher marginal tax rates lead to increases

\footnotetext{
${ }^{1}$ This policy question is even more interesting given the recent finding by Blanchflower, Oswald, and Stutzer (2001) that 70 percent of workers would prefer to be self-employed, while only about 8-14 percent are self-employed.

${ }^{2}$ Of course, the self-employed also accrue the expected returns to failure more directly than employees.
} 
in the self-employment rate. This positive relationship is interpreted as evidence of the evasion and avoidance opportunities available to the self-employed. Robson and Wren (1999) find a negative relationship between the self-employment rate and marginal tax rates, but a positive relationship between average tax rates and the self-employment rate. A recent study by Georgellis and Wall (2002) finds a negative relationship at lower marginal tax rates and a positive relationship at high marginal tax rates. However, studies by Fairlie and Meyer (1998) and Bruce and Moshin (2002) find marginal tax rates have no effect on the self-employment rate.

Some recent studies have emphasized the importance of using individual level data to estimate the tax response. Examples in this literature include Carroll et al. (2000a, 2000b), Bruce (2000, 2001), Bruce and Holtz-Eakin (2001), Gentry and Hubbard (2000), and Cullen and Gordon (2002). One problem that all the recent studies have to address is the endogeneity of the tax rates, which is handled differently depending on the type of data used in the studies. In this paper, we use a difference in differences approach that exploits the exogenous tax reforms of 1986 and 1993. In comparison to the recent studies, this paper is closest in spirit to Bruce (2000), who finds a positive relationship between marginal tax rates and entry into self-employment, and Gentry and Hubbard (2000), who find that a more progressive tax rate structure leads to a decrease in entry into self-employment. However, neither of those studies explicitly treats the tax reforms as natural experiments or uses data from the repeated cross-sections of the SCF. Access to the state identifier in the internal SCF data also allows a more precise computation of tax rates than possible with most other survey data.

To preview the results, we find that marginal and average tax rates are negatively related to the propensity to become self-employed. However, these effects are only significant for the 1986 tax reforms and are sensitive to the model specification. Other factors, such as education, the industry that individual works in, wealth, and attitude toward risk are more constant influences on the choice to become self-employed.

\section{Theoretical Model}

Consider an individual choosing between entering self-employment or becoming an employee. Define the earnings for each sector by the following equations.

$$
\begin{aligned}
& Y_{s e}=\left(1-t_{s e}\right)\left[\theta k^{\alpha}+r(z-k)+q(s)-c\right] \\
& Y_{e}=\left(1-t_{e}\right) w(X)+r z
\end{aligned}
$$

In equation (1), $\theta$ represents entrepreneurial ability, $k$ is amount of capital invested in business, $z$ denotes the assets of the individual, the function $q(s)$ represents non-ability factors that affect self-employment earnings, $c$ is the amount of business expenses, $\alpha$ is in the $(0,1)$ interval, and $t_{s e}$ 
is the tax rate for the self-employed. Equation (2) is the employee earnings equation, where $w(X)$ denotes the wage as a function of human capital variables, $z$ represents the individual's assets, and $t_{e}$ is the tax rate for employees. In both equations, $r$ is equal to the interest rate.

An individual contemplating self-employment must also consider the investment decision, which is represented by equation (3).

$$
\max _{k \in[0, \lambda z]}\left\{\left(1-t_{s e}\right)\left[\theta k^{\alpha}+r(z-k)+q(s)-c\right]\right\}
$$

To model the investment decision more realistically, an exogenous liquidity constraint, $\lambda z$, with $\lambda$ $>=1$, is applied to the investment decision. This liquidity constraint is a multiple of the individual's wealth, which seems like a reasonable assumption given that lenders face an asymmetric information problem when lending to new businesses. Empirical work by Evans and Jovanovic (1989) found $\lambda$ equal to 1.44 , meaning that an individual was able to borrow almost $150 \%$ of the value of his or her wealth. ${ }^{3}$ Equation (3) is solved to yield $k^{*}$, which is the optimal level of capital for the business. If $k^{*}$ is less than or equal to $\lambda z$, then the individual is not liquidity constrained. However, if $k^{*}$ is greater than $\lambda z$, then the individual is constrained to invest only $\lambda z$ in the business.

After solving the investment equation and substituting $k^{*}$ into the self-employed earnings equation, the individual compares the utility derived from the earnings and non-earnings related factors (denoted by $\gamma_{s e}$ and $\gamma_{e}$ ) in each sector to arrive at the choice of work status. ${ }^{4}$ If equation (4) is satisfied the individual chooses self-employment over wage employment.

$$
U\left(Y_{s e}, \gamma_{s e}\right) \geq U\left(Y_{e}, \gamma_{e}\right)
$$

Of course this highly simplified static model leaves out important elements, such as tax evasion and the uncertainty of profits, but the basic idea would remain the same in the presence of those factors. One key idea that the observant reader may have noticed is that the model postulates a different tax rate for the self-employed and employees. Whether that hypothesis is correct can really only be answered by the data, but it is useful to note the differential treatment of the self-employed by the tax code.

Although self-employed and wage/salary workers face the same income tax rate schedule, it is widely believed that the self-employed have more "flexibility" in their reporting of taxable income. Goode (1949) was one of the first to point out that self-employment may offer tax advantages (via avoidance) because of voluntary reporting of income and the deduction of

\footnotetext{
${ }^{3}$ While most studies of the self-employment decision find a positive relationship between wealth and entering self-employment, a recent study by Hurst and Lusardi (2003) calls this result into question.

${ }^{4}$ It is assumed that the utility functions are continuous, concave, and increasing in both arguments.
} 
business expenses. A 1976 IRS study cited by Long (1982b) revealed that only 64 percent of possible self-employment income was reported, compared to 98 percent of wage/salary income. A more recent study by Slemrod, Blumenthal, and Christian (2001) cites the 1988 IRS Taxpayer Compliance Measurement Program, which reports that $99.5 \%$ of wage and salary income is reported, but that only $41.4 \%$ of Schedule $\mathrm{C}$ income is reported. ${ }^{5}$ Thus, there seems some basis for the belief that self-employment offers tax avoidance possibilities.

Aside from the illegally generated differences in income tax rates, there are other differences in how the tax code treats the self-employed versus wage/salary workers. A convenient way to look at these differences is from a historical perspective. Since 1937, the payroll tax has been withheld from wage/salary workers' income to fund Social Security. However, the self-employed were not subject to the payroll tax until 1951, and even then the rate was about 1.5 times the employee rate. ${ }^{6}$ This discrepancy was eliminated in 1984 , and the selfemployment (payroll) tax is now twice the employee rate. Counter balancing the increase in payroll taxes, the 1980's brought about more liberal deductions for the business' use of the home and the deduction of health insurance costs of the self-employed. However, other changes in the 1980 's limited the amount of deductible expenses for the self-employed, and there are still some benefits that wage/salary workers can pay for out of pre-tax dollars that the self-employed cannot. Since 1990, the self-employment tax only applies to 92.35 percent of income and one-half of the self-employment tax can be deducted when computing adjusted gross income (AGI).

Overall, the changes in the tax laws since the 1980's leveled the playing field between the self-employed and wage/salary workers. However, self-employment still offers more flexibility in reporting, since unlike wage/salary workers, there is no third party collecting the tax at the source. Another example of the flexibility in the tax law which the self-employed can take advantage of is the choice of legal structure for their business. At various times since 1980, the top individual and corporate marginal tax rates have flip-flopped in terms of which are higher. For example, in 1987 (after TRA 1986) the top corporate marginal tax rate was 1.5 percentage points higher than the top individual marginal tax rate. However, by 1994 (after OBRA 1993), the top corporate marginal rate was 4.6 percentage points less than the top individual marginal tax rate (Petska, 1998). Thus, the self-employed could alter the legal structure of their business to

\footnotetext{
${ }^{5}$ Slemrod et al. note that underreporting decreases as income increases.

${ }^{6}$ Because the employer matches the amount of payroll tax paid by the employee, the effective payroll tax rate for a wage/salary worker is twice the employee payroll tax rate.
} 
reduce their tax burden, while wage/salary workers have no such options. ${ }^{7}$

The difference in evasion opportunities and how the tax code treats the self-employed versus employees seems to tilt the scales in favor of the self-employed facing lower income tax rates. This implies that increasing tax rates could cause individuals to choose self-employment for the lower tax burden. Of course, if one is willing to assume that returns to success accrue more directly to the self-employed, then an increase in tax rates may result in individuals deciding against self-employment. The progressivity of the tax schedule is the crux of this argument, as a steep schedule may be viewed as a burdensome success tax (Hubbard and Gentry, 2000). Of course, for businesses that are operating at a loss, higher tax rates increase the value of the loss deduction (Cullen and Gordon, 2002). Which effect dominates can only be determined by the empirical work. ${ }^{8}$

\section{Econometric Methods}

\subsection{Identifying Tax Effects}

Since estimating the effects of taxation is the purpose of this paper, we need to address the econometric problems associated with identifying tax effects. It is well known that identifying the effects of a change in the Federal tax law is hindered by the fact that all individuals with a given set of characteristics face the same tax rate at a given point in time. This lack of variation makes estimating the effect of taxes difficult, and in some cases identification arises only from the non-linearity of the tax function. Plus, since earnings are a component of the tax function, and earnings and the employment decision occur simultaneously, the tax rate is endogenous.

The issue of identifying tax effects figures prominently in the recent literature on taxes and labor supply and the literature on taxes and taxable income. ${ }^{9}$ One method that has gained widespread use is "differences in differences" (DID). This method is similar to the treatment effects idea, where one group is exposed to some sort of catalyst (treatment group), while the other group is not (control group). Usually DID is utilized to examine the effects of a natural

\footnotetext{
${ }^{7}$ Of course, changing the legal structure of a business is not without its costs. However, previous research referenced in Petska (1998) shows that after TRA 1986 businesses shifted to legal structures that were taxed at the individual versus corporate level. Changing the legal structure of a business also may be a form of income shifting, which is discussed in Gordon and Slemrod (2000).

${ }^{8}$ Another potential issue is whether individuals believe that the tax reforms will be offset by opposing reforms in the future. This issue is not as relevant for TRA86, since that act was revenue neutral. However, OBRA93 targeted high-income taxpayers, and individuals may have (rightly) believed that future administrations would undue the tax rate increases.

${ }^{9}$ Examples from this literature include panel data studies such as Feldstein (1995), Navratil (1995), Auten and Carroll (1999), Moffitt and Wilhelm (2000), Goolsbee (2000), and Gruber and Saez (2000). Studies using repeated cross-section data include Lindsey (1987), Feenberg and Poterba (1993, 2000), Eissa (1995, 1996a, 1996b), and Feenberg and Feldstein (1996).
} 
experiment on two different groups. The two main assumptions behind the DID methodology are that individuals are grouped by an exogenous variable and that the growth rate of the dependent variable for the two groups is equal in absence of the treatment. ${ }^{10}$ DID estimates can be computed using a simple tabular method or by regression analysis. ${ }^{11}$ An example of a possible DID regression model is as follows.

$$
\begin{aligned}
& C_{i t} *=\alpha+\gamma_{1} Y R_{t}+\gamma_{2} G_{i}+\gamma_{3} Y R_{t} G_{i}+X_{i t}{ }^{\prime} \beta+\varepsilon_{i t} \\
& C_{i t}=1 \text { if } C_{i t} * \geq 0 \\
& \quad=0 \text { if } C_{i t}^{*}<0
\end{aligned}
$$

In equation (5), one pools data from a year prior to the change in the tax laws together with data from a year after the tax reform. The dependent variable is a binary response for whether an individual is self-employed at time $t, Y R_{t}$ is a dummy variable equal to 1 if the observation is from the post-intervention year, $G_{i}$ is a dummy variable equal to 1 if the individual belongs to the treatment group, $Y R_{t} G_{i}$ is a dummy variable equal to 1 if the individual is in the treatment group in the post-intervention year, $X_{i t}$ is a vector of individual characteristics, and $\varepsilon_{i t}$ is the error term. In equation (5), the coefficient of interest is $\gamma_{3}$, which is the effect of the treatment on the outcome for the treated group.

The simplicity of the DID methodology masks some important underlying econometric issues. Moffitt and Wilhelm (2000) discuss many of these problems in detail, but we will just highlight the key points here. One result from Moffitt and Wilhelm is that when identifying tax effects using DID, the grouping variable acts as an instrumental variable for the tax function, since the tax function itself is endogenous. Another important result is that the grouping variable should be exogenous and time-invariant. These results imply that using income, a seemingly obvious grouping variable for studying tax changes, is problematic.

First note that the use of income as a grouping variable in this study violates the assumption of having an exogenous grouping variable. This is because one can argue that the choice of being self-employed or an employee and contemporaneous income are jointly determined. If income is simultaneously determined with employment status, then income is also likely to be correlated with the unobservables. Since the instrument (income) is correlated with the error term (or the difference in the error terms) it is not a valid instrument for the tax function. ${ }^{12}$ Another issue that arises when using RCS data is we cannot follow the same

\footnotetext{
${ }^{10}$ The first assumption is analogous to a condition necessary to apply the Wald estimator.

${ }^{11}$ Meyer (1995) provides an excellent overview of the use of natural experiments and DID.

${ }^{12}$ A valid instrument is correlated with the endogenous variable, but uncorrelated with the error term.
} 
individuals across time, so we must assume that no individuals switch groups. This is where choosing a time-invariant grouping variable is important. If we choose a relatively time-invariant characteristic, such as education or occupation, to group individuals, then we eliminate the bias the switchers may cause. ${ }^{13}$

A final issue with DID is the assumption that the growth rate of the dependent variable for the two groups is equal in absence of the experiment. This assumption is important because it ensures that the changes in the dependent variable are due to the experiment and not other factors. Thus, we want groups for which the growth rate of self-employment moves in similar ways in periods without any tax changes. Since we have data from a period without any marginal tax rate changes, this assumption is testable.

With the above problems in mind, we need to find grouping variables that avoid all the potential pitfalls. Possible candidates for grouping variables are education and occupation. To ensure time-invariance of these variables it is necessary to restrict the sample to individuals who have completed their education (older than 24) or group individuals by broad occupation categories (blue collar vs. white collar). Education and occupation should also be strong instruments for the tax function, since they are correlated with income. A strong instrument is one in which there is substantial variation in marginal tax rates across the groups created by the instrument. We assess the strength of the instruments by using F-tests in the first-stage regressions.

\subsection{Repeated Cross-Section Analysis}

Although RCS analysis may sound unfamiliar to some, variants of RCS analysis appear constantly in economics. Any estimation that uses aggregate data is a special type of RCS analysis, which is common in empirical macroeconomics. The application of RCS analysis in microeconomics most commonly entails constructing birth cohorts in the data, so that the population of individuals in different years remains the same. Stratifying the data by birth cohorts allows members of the population age into or age out of the sample. ${ }^{14}$

An important microeconomic study that uses RCS methods is Browning, Deaton, and Irish (1985), who use British household survey data to study consumption and labor supply issues. The variables used in their models are constructed by computing means over cohort-year groups. An example of this "pseudo" panel data approach is given by equation (6).

$$
\bar{y}_{c t}=\bar{x}_{c t} \beta+\bar{f}_{c t}+\bar{\varepsilon}_{c t}
$$

\footnotetext{
${ }^{13}$ See Heckman (1996) for an example of the bias these switchers may cause.

14 This assumes the population has no in or out flows of immigrants and no births or deaths.
} 
In equation (6), $\mathrm{c}$ indexes the birth cohort (say five year intervals), $t$ is the time period, and the overbar denotes the mean over the individuals in the given cohort-year group. This formulation reduces the individual data down to group means, and the regressions are estimated on these observations. However, $\bar{f}_{c t}$ is an error-filled estimate of the true cohort fixed effect, plus the individual fixed effect is unobserved and can be correlated with $\bar{x}_{c t}$. A possible solution to this problem is to construct cohorts of a sufficient size so that the problems are ignorable. Work by Nijman and Verbeek (1992) shows that if cohort size is 100-200 observations and there is time variation in the means, these problems can be ignored.

The Browning, Deaton, and Irish study fostered other work on the econometric properties of RCS estimation, most notably by Deaton (1985), Nijman and Verbeek (1990, 1992), and Moffitt (1993). Moffitt's study shows that estimation of RCS models can proceed using the individual level data, and he provides insight on the identification issues with RCS methods. Furthermore, he stresses the importance of stratifying the data by time-invariant characteristics and shows that RCS estimation is a version of instrumental variable estimation.

In terms of using RCS methods in this paper, we present a modified version of equation (5).

$$
\begin{aligned}
& C_{i t} *=f_{i}+\gamma T_{t}\left(Z_{i t}\right)+V_{i t}^{\prime} \beta+\varepsilon_{i t} \\
& C_{i t}=1 \text { if } C_{i t} * \geq 0 \\
& \quad=0 \text { if } C_{i t} *<0
\end{aligned}
$$

In equation (7), $f_{i}$ is the individual specific fixed effect, $T\left(Z_{i t}\right)$ is the tax rate function, $V_{i t}$ is a vector of all the other covariates, and $\varepsilon_{i t}$ is as previously defined. Equation (7) is estimated on the pooled cross-section data, which consists of data from before and after the change in the tax laws.

There are numerous problems with equation (7), the first being that since we have crosssection data, the fixed effect is unobserved. This will lead to omitted variable bias if any of the other variables in equation (7) are correlated with the unobserved fixed effect. It is obvious that the tax function is correlated with the unobserved fixed effect, as well as being correlated with the error term. As discussed previously, the main reason for this is that income is an argument in the tax function. Other covariates in $V_{i t}$ are unlikely to be highly correlated with the unobserved fixed effect, since most of them vary over time. If any of the variables in $V_{i t}$ are correlated with the error term, then the usual IV methods can be implemented to correct for the endogeneity. As for the time-invariant variables in $V_{i t}$, they are considered proxies for the fixed effect. Redefine the fixed effect as in equation (8). 
$f_{i}=\phi_{1} G_{i}+C D_{i}^{\prime} \phi_{2}+S_{i}^{\prime} \phi_{3}+v_{i t}$

In equation (8), $G_{i}$ is the grouping variable, $\mathrm{CD}_{\mathrm{i}}$ is a vector of cohort dummies, $S_{i}$ is a vector of all the time-invariant variables in $V_{i t}, \phi_{1}, \phi_{2}, \phi_{3}$ are the coefficient vectors, and $v_{i t}$ is the error term.

Since the tax function is correlated with the unobserved fixed effect we need an instrument that is correlated with the tax function, but uncorrelated with the fixed effect. A timevarying variable would seem to be a good choice, since the fixed effect is time-invariant.

However, using a time-varying variable to instrument for the tax function leads to problems with the DID methodology, since we do not want to group individuals by a time-varying characteristic. The solution to this problem is to use a combination of time-invariant and time-varying variables, such as an education and year interaction.

Equation (9) shows explicitly how we instrument for the tax function.

$$
\widehat{T_{t}\left(Z_{i t}\right)}=C D_{i}^{\prime} \pi_{1}+S_{i}^{\prime} \pi_{2}+W_{i t}^{\prime} \pi_{3}+\pi_{4} Y R_{t} G_{i}+\pi_{5} Y R_{t}+\pi_{6} G_{i}+u_{i t}
$$

In equation (9), all variables are as previously defined, with $W_{i t}$ a vector of all the exogenous time-varying variables in $V_{i t}$ and $u_{i t}$ the error term. The instrument for the tax function is $Y R_{t} G_{i}$, which is the interaction of the education grouping variable and a year dummy, which is equal to one for highly educated individuals in a year after the tax law change.

Using the interaction term as an instrument for the tax function also solves the problem of identifying tax effects. Since some of the variables in the tax function $\left(Z_{i t}\right)$, are likely to also appear in $V_{i t}$ (such as number of children and marital status), if we do not instrument for the tax function, then identification comes from the non-linearity in the tax function. Substituting the estimated tax rate and the equation for the fixed effect (equation (8)) into equation (7) and excluding the instrument yields the equation estimated on the data.

$$
\begin{aligned}
& C_{i t} *=C D_{i}^{\prime} \delta_{1}+S_{i}^{\prime} \delta_{2}+\delta_{3} Y R_{t}+\delta_{4} G_{i}+\delta_{5} \widehat{T_{t}\left(Z_{i t}\right)}+W_{i t}^{\prime} \delta_{6}+\eta_{i t} \\
& C_{i t}=1 \text { if } C_{i t}^{*} \geq 0 \\
& \quad=0 \text { if } C_{i t} *<0
\end{aligned}
$$

Since the dependent variable is binary, we estimate equation (10) using a probit model. Due to the endogeneity of the tax function, we use the procedure outlined in Newey (1987) for asymptotically efficient estimation of a binary choice model with endogenous independent variables. The key idea is the use of the Amemiya Generalized Least Squares (AGLS) estimator 
(Amemiya, 1978) to estimate the structural coefficients, after first estimating the reduced form parameters. $^{15}$

\section{Data and Sample Characteristics}

\subsection{Data}

The datasets we utilize in this paper are the 1983, 1989, 1992, 1995, 1998, and 2001 Survey of Consumer Finances (SCF). The Board of Governors of the Federal Reserve System conducts this survey of household assets and liabilities on a triennial basis. ${ }^{16}$ Besides collecting information on assets and liabilities, the SCF collects information on household demographics, income, relationships with financial institutions, attitudes toward risk and credit, current and past employment, and pensions. Sample sizes for the SCF range from 3,143 to 4,442 households.

The SCF uses a dual frame sample design to improve coverage of all households in the United States. One part of the sample is an area probability sample derived from the Census Bureau's national sampling frame, while the other part, the list sample, uses the IRS Statistics of Income Individual Taxpayer File to oversample wealthy households in the population. This dual frame design provides the SCF with coverage of assets widely held in the population, such as cars or houses, and assets narrowly held in the population, such as private businesses and bonds.

Wealth data from the SCF are widely regarded as the most comprehensive data available for the United States.

Sample weights constructed for the SCF allow aggregation of estimates to the U.S. household population level in a given survey year. Missing values in the 1983 SCF are replaced using a single imputation technique, while missing values in the 1989-2001 SCF are replaced using a multiple imputation technique. The main advantage of multiple imputation over single imputation is the efficiency of estimates. ${ }^{17}$

Due to the richness of the SCF data, we are able to control for a variety of factors that may influence the decision to become self-employed, such as education, current job tenure, labor force experience, industry, occupation, geographic location, marital status, number of children, health, attitudes toward risk, expectations of inheritance, wealth, credit worthiness, and previous

\footnotetext{
${ }^{15}$ The Stata command that performs this procedure was written by Joe Harkness and is available to download at http://ideas.uqam.ca/ideas/data/Softwares/bocbocodes415801.html.

${ }^{16}$ Other agencies have or continue to play important roles in the SCF. For the 1983 and 1989 surveys, the Survey Research Center at the University of Michigan conducted the fieldwork and contributed to the survey design. The Department of Health and Human Services also contributed greatly to the 1983 SCF. From 1992 forward, NORC, a research organization at the University of Chicago, has conducted the fieldwork. Agencies such as the IRS-SOI and the Office of Tax Analysis have played vital roles throughout all of the SCFs.

${ }^{17}$ Kennickell (1998a) discusses the list sample design, Kennickell $(1991,1998 b)$ discusses the multiple imputation technique, and Kennickell and Woodburn (1999) and Kennickell (1999) discuss the weighting methodology used in the SCF.
} 
self-employment experience. Comprehensive income data for the year prior to the survey are also collected by the SCF, and this, in conjunction with the other data in the survey allows for the computation of Federal and state tax rates (marginal and average) and liabilities via the NBER TAXSIM model. ${ }^{18}$

We examine marginal and average tax rates because each provides a conceptually different measure of the household's tax rate. While marginal tax rates represent the tax rate on additional earnings, average tax rates provide a measure of the tax rate for total taxable income. Both tax rates are computed on a household level basis, with marginal rates computed by adding $\$ 1$ to earnings. The average tax rate is the ratio of the total tax liability (Federal and state) to total income (minus non-taxable income) of the household. Since we are only examining the household head's self-employment decision, it is assumed that all other income flows in the household except for the head's earnings and business income remain unchanged when employment status changes. Married couples are assumed to file jointly, as are couples that live together. The SCF does ask about the household's filing status, and some married couples do report filing separately. Unfortunately, due to the difficulty in dividing up the income flows and tax deductions, we assume that married filing separately and cohabitating couples file jointly. The effect this assumption has on the tax rates is not clear, since it depends on the division of income flows and deductions between the two taxpayers. ${ }^{19}$ Only about 2-6 percent of all households across all survey years are couples living together, and only about 3-14 percent of married couples file separately across all survey years.

The computation of the tax rates includes using the SCF data to calculate the value of itemized deductions; this includes the mortgage interest deduction, property tax deduction, charitable contributions deduction, investment interest expense deduction, personal interest deduction (in applicable years) and state tax liability deduction. While our definition of itemized deductions does not include all deductions, the items contained in our measure account for 80 to 90 percent of total itemized deductions in any given survey year. Comparisons of the number of returns, returns by filing status, number of itemizers, and itemized deduction amounts in aggregate and by adjusted gross income classes between values in the IRS Statistics of Income

\footnotetext{
${ }^{18}$ For a description of the TAXSIM model, see Feenberg and Coutts (1993) or visit www.nber.org/ $/$ taxsim/.

${ }^{19}$ For example, consider a couple living together where the household head has $\$ 70,000$ in wages, the partner has $\$ 30,000$ and they have no other income. In 1997, filing individually, the household head's federal marginal tax rate is $31 \%$, while the partner's federal marginal tax rate is $15 \%$. But if they file jointly, their federal marginal tax rate is $28 \%$. If both individuals had wages of $\$ 50,000$, then each would face a federal marginal tax rate of $28 \%$ filing as a single taxpayer, and would face a $28 \%$ federal marginal rate if filing jointly.
} 
Individual Income Tax Returns and the SCF data reveal a high degree of similarity. For example, if we compare the aggregate amount of itemized deductions from a given year of the SCF to the IRS value for that year, the largest possible discrepancy is deductions in the SCF being 10 percent larger. $^{20}$

In addition to federal and state tax rates, we also include the payroll tax rate in the tax rate measure. We assume that employees pay both the employee and employer part of the payroll tax. The marginal payroll tax rate is computed by adding $\$ 1$ to the earnings of the household head, while the average payroll tax rate is the ratio of the household head's payroll tax liability to the household head's earnings. Since the self-employed faced a lower rate than employees prior to 1990 , and since the payroll tax is a significant percentage of earnings (up to a maximum amount), it is important to include the payroll tax in the total tax rate measure. ${ }^{21}$

The sample period of 1983-2001 covers the major federal tax rate changes of 1986 and 1993, and the lesser change in 1990. Table 1 shows how rates have changed for married filing jointly households. The Tax Reform Act of 1986 (TRA86) reduced the number of statutory personal tax rates from twelve to two (15\% and $28 \%)$, with a "bubble" rate $(33 \%)$ for a certain range of taxable income. In 1990, the Omnibus Reconciliation Act (OBRA90) removed the 33 percent "bubble" rate, and created a 31 percent tax rate. This act also introduced limits on itemized deductions and modified the phaseout of personal exemptions. Since the "bubble" rate of 33 percent existed prior to OBRA90, the creation of the 31 percent rate actually was a tax rate decrease for some households, and a tax rate increase for others. These opposing changes make it difficult to disentangle the tax effects, which is why we also choose not to focus on the OBRA90 rate change. The Omnibus Reconciliation Act of 1993 (OBRA93) created two new high-income tax brackets of 36 and 39.6 percent, plus the limits on itemized deductions and the phaseout of personal exemptions were made permanent. Although the Taxpayer Relief Act of 1997 (TRA97) changed significant elements of the tax code, marginal rates were not changed. ${ }^{22}$ The cut in marginal tax rates in the Economic Growth and Tax Relief Reconciliation Act of 2001 (EGTRRA01) does not affect the $2001 \mathrm{SCF}$, since the tax rates are computed for the year prior to the survey year.

\footnotetext{
${ }^{20}$ More information on the computation of tax rates and itemized deductions is available from the author upon request. In the near future, the author hopes to make the programs that perform these calculations available to the public and produce a detailed comparison study.

${ }^{21}$ Although workers do derive Social Security and Medicare benefits from payroll tax contributions, Feldstein and Samwick (1992) show that the net marginal social security tax rate varies widely among workers.

${ }^{22}$ One can argue that the reduction in capital gains rates in TRA97 could affect the self-employment decision. Unfortunately, modeling that effect is beyond the scope of this paper.
} 
Thus, over the 1989 to 1992 period there was a very small change in marginal rates, while from 1995 to 1998 and from 1998 to 2001 no change in marginal rates occurred. Whether it is correct to classify any of these periods as void of significant tax rate changes is debatable. More discussion on this point is delayed until the analysis of the changes in the self-employment rates in Table $2 b$.

\subsection{Sample Characteristics}

The first sample related issue that needs to be addressed is how to define the selfemployed. Many theoretical definitions are possible, and due to the richness of the SCF data, numerous empirical definitions are available. The two definitions considered for the analysis are a self-reported measure of self-employment and a combination of the self-reported measure and information on businesses owned by the household. For the self-reported measure of selfemployment, individuals are classified by their response to a question about whether they work for someone else or they are self-employed. ${ }^{23}$ The second definition of self-employment uses the self-reported measure in conjunction with the question about whether the household owns an actively managed business. ${ }^{24}$

The critical difference between the two definitions is the presence of an actively managed business in the data. For the first definition, we have individuals who report being self-employed, but report no businesses in the business information section of the SCF. Whether we want to consider these individuals self-employed is debatable, but there are plausible reasons why a selfemployed individual might not report business information. One reason is that the business could be new or in the early stages of development. A second reason could be the type of industry or occupation the individual works in. Self-employed consultants are good examples, as they may not have many tangible business assets. However, if they are working independently and bear all the earnings risk, we argue they should be considered self-employed. The fact that a selfemployed individual bears all the earnings risk is the key element of our definition of selfemployment, which is derived from the ideas put forth by Knight (1921).

Examination of the industry and occupation of the self-employed that report no business information reveals that majority of these individuals are in agriculture / construction / mining or service based industries (such as finance, insurance, real estate, professional services, or business and repair services). The most common occupations for this group include manager,

\footnotetext{
${ }^{23}$ The text of this question has changed somewhat over the course of the survey, but not in a way that should greatly influence responses. The specific variable used in the self-reported measure is B4540 in the 1983 SCF and X4106 in the 1989, 1992, 1995, 1998, and 2001 SCFs.

${ }^{24}$ By construction, the second definition is a subset of the first definition. Also, only non-publicly traded businesses are reported in the section on businesses in the SCF. Ownership in publicly traded companies would be recorded by the questions about public stock holdings.
} 
professional, craft, and repair occupations. As expected, many of these industries or occupations are those that do not require a large amount of initial capital or the existence of separate business assets.

As was mentioned in the econometric section of the paper, the choice of grouping variable is a key element in correctly implementing the DID methodology. The main grouping variable we use in this paper is the education level of the household head. Under the first education definition, the control group contains individuals with a high school diploma or less, while the treatment group consists of individuals with at least some college education. Under the second definition, the control group contains all individuals without a college degree, while the treatment group consists of individuals with at least a college degree. As an attempt to remove individuals who have not completed their education, we restrict the sample to household heads who are at least age 25 and who are currently working. To avoid retirement issues, households with heads aged 65 or older are omitted from the sample. No restriction on the minimum number of hours worked per week or weeks work per year is used, since flexibility of work schedule is a potential benefit of self-employment. Since we are focusing on personal tax rates, self-employed individuals whose businesses are organized as privately held C-corporations are also dropped from the sample. Privately held C-corporations are treated as separate entities from their owners for tax purposes, unlike partnerships, sole proprietorships, and S-corporations. We also only focus on male household heads, as there are other issues unique to females that preclude including them in the sample. ${ }^{25}$

The data is also grouped into cohorts by restricting the sample for each year of the crosssection to include only the appropriately aged sample. For example, when studying the 1986 Tax Reform Act, we use the 1983, 1989, and 1992 SCF. Since the sample is restricted to individuals age 25 to 64, the 1983 sample only includes individuals age 25 to 55, the 1989 sample only includes individuals age 31 to 61, and the 1992 sample only includes individuals age 34 to 64 . By constructing the sample in this manner, we create a synthetic panel of individuals who age over time.

As the most basic check on the validity of education as the grouping variable, Table $2 \mathrm{a}$ shows the percent of households in the treatment group for each education definition, by year and sample. Imputation and sample adjusted standard errors are listed in italics for all years but 1983, since the necessary information to compute the standard errors for the 1983 is not available. In the TRA86 sample, there is somewhat of an upward trend in the percent of households in the

\footnotetext{
${ }^{25}$ The most obvious example is childbearing. Devine (1994) provides detailed information on selfemployed women.
} 
treatment group, regardless of the education definition. While the change in treatment group membership is statistically significant over the 1989 to 1992 time period, it is unclear whether the change between 1983 and 1989 is significant. However, if the standard errors for the 1983 estimates are the same proportion of the estimate as in later years, the difference between 1983 and 1989 would be significant.

The increase in the percent of households with higher education is widespread in the sample across all age groups and across both employees and the self-employed. This general trend is evident across both employees and the self-employed and across all age groups. In the OBR93 sample, the percent of households in the treatment group for each education definition is much more stable over time; almost of all of the year-to-year changes are insignificant. Thus, the grouping variables are more suspect for the TRA86 sample than for the OBRA93 sample.

Table $2 \mathrm{~b}$ shows the self-employment rates in each year for the two self-employment definitions and for the different education definitions. ${ }^{26}$ The first point from Table $2 b$ is that the time trend of the overall self-employment rate is the same regardless of the definition of selfemployment. In the TRA86 sample, the self-employment rate is rising, with a sizable jump between 1983 and 1989. For the OBRA93 sample, the changes are less dramatic, but there is a decrease in the rate between 1992 and 1995. However, note that the decrease between 1992 and 1995 is statistically insignificant for both definitions of self-employment.

Similar trends are evident in the education-specific self-employment rates. The treatment groups under both education definitions show increases in both self-employment measures over the 1983 to 1989 time period. Over the 1992 to 1995 period, the decreases in the self-employment rates for the treatment groups are only significant for the college or higher group. One notable deviation from the overall trend is for the some college or less group for the self-reported measure of self-employment. For this group, there is a drop in the self-employment rate between 1989 and 1992 in the TRA86 sample, a rise in the rate between 1992 and 1995 in the OBRA93 sample, and a slight drop in the rate between 1998 and 2001 in the OBRA93 sample. However, all of these changes are statistically insignificant. Overall, Table 2 shows some evidence of a negative relationship between self-employment rates and changes in tax rates. ${ }^{27}$

The information on self-employment rates by education group in Table $2 \mathrm{~b}$ can also help determine if the growth rate of the self-employment rate is equal for the treatment and control groups in periods without a major tax rate change. First, focus on the self-reported measure of

\footnotetext{
${ }^{26}$ Imputation and sample adjusted standard errors are in italics. It is not possible to compute correct standard errors for the 1983 data due to the lack of sample information.

${ }^{27}$ For a comparison between the self-employment rates reported in Table 2 and rates from the Current Population Survey, see the appendix.
} 
self-employment and the first education definition. In the TRA86 sample over the 1989 to 1992 period, when there was a minor tax rate change, both groups experience increases in their selfemployment rates, but the growth rate was slightly higher for the high school or less group. As mentioned earlier, no marginal tax rate changes occurred over the 1995 to 1998 or 1998 to 2001 time periods. Examining these periods in the OBRA93 sample, we see that the self-employment rate increased for both groups, with a significant increase for highly educated individuals over the 1995 to 1998 time period.

Turning to the second education definition (for the self-reported self-employment measure), a somewhat different pattern emerges. In the TRA86 sample over the 1989 to 1992 period, the college or higher group experiences a significant increase in their self-employment rate, while the rate for the some college or less group decreases by an insignificant amount. In the OBRA93 sample, for the 1995 to 1998 time frame, both groups show an increase in their selfemployment rate, with a higher growth rate for the college or higher group. Over the 1998 to 2001 time frame, the college or higher group experiences a rise in their self-employment rate, while the self-employment rate for the some college or less group slightly decreases. Both of these changes are insignificant.

While some of the changes in self-employment rates in the 1989 to 1992,1995 to 1998 and 1998 to 2001 time periods seem to violate the DID assumption about equal growth rates in periods without interventions, there are reasons why all these periods may be tainted. For the 1989 to 1992 time period, the most obvious reason is that there was a small tax rate change in 1990 (OBRA90). This small rate change affected only higher income households, and since income and education are positively related, the effects were not evenly distributed across the treatment and control groups. For the 1995 to 1998 and the 1998 to 2001 time periods, although there was no change in marginal rates in TRA97, the tax rate on capital gains decreased for most assets. Any relationships between the self-employment decision and capital gains rates could also potentially taint these periods. While there are concerns about the appropriateness of using education as the grouping variable, the first stage regressions will provide an additional test of the validity of the grouping variable.

Another issue related to the choice of grouping variable is whether there is significant variation in tax rates between education groups. By definition, the treatment group should be more affected by the change in tax rates than the control group. Table 3 shows the total marginal and average tax rates by education group. Focusing on the first education definition in Table 3, we see that the high school or less group experienced over a four-percentage point decline the average marginal tax rates between 1983 and 1989. In contrast, average marginal tax rates for the 
highly educated group fell almost twice as much over the same time period (44.5\% to $36.7 \%$ ). Over the 1992 to 1995 period, both groups experienced a similar increase in average marginal tax rates, which seems problematic for the grouping variable.

However, because OBRA93 only affected very high income tax filers (joint filers with over $\$ 165,000$ in taxable income, see Table 1), and TRA86 was more wide-ranging, this result is not surprising. Examining the second education group definition, where the treatment group consists of household heads with a college degree or higher, reveals a 0.7 percentage point increase in the average marginal tax rate over the 1992 to 1995 period. This change borders on being statistically significant. In contrast, there was no change in the average marginal tax rate for the some college or less group. Results for the second education group definition for the 1983 to 1989 time frame are similar to results for the first education group definition.

Average tax rates vary much less than marginal tax rates for all education groups across all time periods. Nonetheless, the declines in average tax rates for the 1983 to 1989 time period are larger for the highly educated households compared to households with less education. For example, over the 1983 to 1989 period, average tax rates for the some college or higher group declined two percentage points, while average tax rates for the high school or less group declined 0.5 percentage points. Over the 1992 to 1995 time frame, average tax rates also varied more for the highly educated groups and the changes are statistically significant. Table 3 shows that there is greater variation in both tax rates for the treatment group in the periods with tax reforms. While the tax rate changes in Table 3 show the unconditional differences by education group, these differences are likely to change once we control for other variables in the regressions of the tax rates on other covariates (Table $6 \mathrm{a}$ and $6 \mathrm{~b}$ ).

Table $4 \mathrm{a}$ and $4 \mathrm{~b}$ present the summary statistics by year and by the self-reported measure of self-employment for the two samples used in main estimations in the paper. ${ }^{28}$ While not all of the variables in Tables $4 \mathrm{a}$ and $4 \mathrm{~b}$ appear in the regression analysis, the tables provide information on the differences between the self-employed and employees. The first thing to note from Table $4 \mathrm{a}$ or $4 \mathrm{~b}$ is that the self-employed have a lower mean marginal tax rate in all years, but the standard deviation is higher in all years. This result also holds true for mean average tax rates, except in 1992 in the TRA86 sample, where the mean average tax rates are essentially equal. Examining the other variables in the tables reveals that the self-employed have higher average

\footnotetext{
${ }^{28}$ Median values for selected characteristics are shown in the appendix, Table A2. Similar tables for the self-reported and "has an active business" definition of self-employment are available from the author upon request.
} 
earnings, income, net worth, and larger standard deviations for these variables too. ${ }^{29}$

The self-employed are also more likely to be highly educated, have a longer tenure at their current job, work more weekly hours, and be more willing to take financial risks. Two-thirds of the self-employed are employed in manager / professional / technical / sales occupations and the self-employed work mostly in industries other than manufacturing. In terms of the legal structure of businesses of the self-employed, the majority are sole proprietorships, with partnerships and Scorporations the next most common organization forms. Note that although the self-reported measure of self-employment does not require the existence of a business in the data, about 70 percent of the self-employed have an actively managed business. Obviously there are many possible comparisons in Tables $4 \mathrm{a}$ and $4 \mathrm{~b}$, but we will save further analysis for the regression results.

\section{Results}

Before we discuss the results for the tax variables, we present the results for the pooled self-employment choice equation without the tax variables. ${ }^{30}$ Table $5 \mathrm{a}$ and $5 \mathrm{~b}$ show the results for the TRA86 and OBRA93 samples, with the potential instruments included in the model. Most of the variables have the expected signs, and the results are consistent across both samples and most time periods. Education has a positive effect and significant effect in most years, which is result found in many other studies. Tenure at the individual's current job exhibits a positive, but decreasing effect, which is a common finding in these types of models. Industry plays an important role in the self-employment choice decision, with the self-employed favoring nonmanufacturing industries.

The results for the race variable are similar to other studies in the literature; white individuals are significantly more likely to be self-employed. In terms of attitudes toward risk, individuals that are willing to take above average financial risks are significantly more likely to be self-employed in most time periods. This result provides empirical evidence for the theoretical

\footnotetext{
${ }^{29}$ Comparing the pre-tax earnings of employees and the self-employed involves a number of issues. First, one could argue that employee earnings are understated by the amount of payroll taxes paid by employers. Since the self-employed pay both parts of the payroll tax, their pre-tax earnings may be higher. Second, we can only compare monetary earnings, and cannot account for the value of fringe benefits for either group. While these issues are important, they are beyond the scope of this paper. As noted in the data section, we do include payroll taxes in the tax rate measure.

${ }^{30}$ All regressions are weighted and adjusted for the effects of multiple imputation on the coefficients and standard errors. Because the 1983 data is only singly imputed, we created five replicates of the 1983 data to facilitate the computation of the adjustment for multiple imputation over the 1983 to 1989 time period. To assess the influence the replicating had on the results, we replicate one implicate of the 1989, 1992, 1995 and 1998 data five times and estimate our models. While we would expect the replicated data to produce smaller standard errors in the regressions, this was not always the case. In fact, often the standard errors were higher in the replicated data. Overall, the replicating the 1983 data produces standard errors that are about two percent larger, which will not affect the highly significant coefficients in the regressions.
} 
link between risk taking and self-employment. Log of house value is used as a proxy for wealth in our study and has a positive effect on self-employment, but is only significant after the 1989 to 1992 time period. This result lends some support to the idea that capital constraints play an important role in the self-employment decision. Over the 1983-1989 time period, the state level unemployment rate has no significant effect on self-employment, but over the 1989 to 1992 and 1992 to 1995 periods the state unemployment rate has a positive and significant effect. As in other studies in the literature that use state unemployment rates, such as Schuetze (1998), it appears that higher unemployment can push individuals into self-employment. ${ }^{31}$ Previous selfemployment experience has a strong positive and significant effect on choosing self-employment, as shown by the variable indicating if the household head was self-employed on his longest prior job. $^{32}$

Turning now to the models with the tax variables, Table $6 \mathrm{a}$ and $6 \mathrm{~b}$ show the results of the first stage regressions of the tax rate variables on the various instruments and the other exogenous variables. $^{33}$ To ensure we have strong instruments we include the F-statistic for the test of the null hypothesis that the coefficient on the instrument is weak. As shown in Stock, Wright, and Yogo (2002), a significant coefficient on the instrument and a low p-value for the F-statistic is not enough to guarantee a strong instrument. Stock and Yogo (2002) provide critical values for the F-statistic that identifies strong instruments (Table 2 in their paper). For a single endogenous regressor and a single instrument, the critical value for a 5\% Wald test that has an actual size potentially exceeding $10 \%$ is 16.38 , and for $15 \%$ is 8.96 .

In Table 6a, for the 1983 to 1989 time period and either tax rate, both instruments for marginal tax rates have F-statistics that exceed the critical values, but for average tax rates only the some college*1989 instrument has a sufficient F-statistic. Over the 1989 to 1992 time frame, neither of the instruments have a large enough F-statistic. In Table $6 \mathrm{~b}$, none of the instruments in the 1992 to 1995 or 1995 to 1998 periods have F-statistics that exceed the critical values, but the some college*2001 instrument is strong for marginal tax rates over the 1998 to 2001 period. The lack of strong instruments for the 1992 to 1995 period is troubling, but we defer the discussion of this problem until we test the sensitivity of the results. Given the weak instrument problem for the OBRA93 sample, the primary focus will be on the results for the TRA86 sample.

\footnotetext{
${ }^{31}$ There is no clear consensus in the literature on the effect of unemployment on self-employment. For example, Bruce (2000) finds a negative relationship when using county level unemployment rates.

${ }^{32}$ Evans and Leighton (1989) also find a positive effect of previous self-employment experience.

${ }^{33}$ While all other exogenous variables are included in the regressions, only the time and group dummies are listed in Table $6 \mathrm{a}$ and $6 \mathrm{~b}$ to save space.
} 
With two definitions of self-employment, two definitions of education groups, two definitions of tax rates, and two samples, reporting the results of all the possible estimations would be overwhelming. We focus on the self-reported definition of self-employment for both education definitions. ${ }^{34}$ Results for both the marginal and average tax rates are presented in Table $7 \mathrm{a}$ and $7 \mathrm{~b}$.

Beginning with the TRA86 sample over the 1983 to 1989 time period, Table 7a shows a negative effect of the total marginal tax rate on the propensity to choose self-employment. This relationship exists regardless of the education group definition or the tax rate measure, but the coefficient is only significant for the marginal tax rate using the some college *1989 instrument. We find no significant tax effects over the 1989 to 1992 time period, which is to be expected given the lack of strong instruments. For the OBRA93 sample, Table $7 \mathrm{~b}$ shows no significant results for either of the tax rate measures in all time periods. Of course, with the lack of strong instruments this result is not surprising. For the 1992 to 1995 period, although the tax rate effects are insignificant, the negative effect of the marginal tax rate is consistent with the results from the TRA86 sample.

While we do find a negative and significant effect for marginal tax rates over the 1983 to 1989 period using the some college*1989 instrument, the lack of significant results using the college*1989 instrument calls the robustness of the result into question. Plus, the marginal effect of the marginal tax rate is rather large; a one percentage point decrease in the average marginal tax rate leads to a one-percentage point increase in the self-employment rate. Given that the average marginal tax rate for all households fell 6 percentage points between 1983 and 1989, the calculated change in the probability of being self-employed is over 7 percentage points. This is rather large considering the self-employment rate over the 1983 to 1989 period was 14.1 percent.

\section{Sensitivity of the Results}

The two main concerns with the results are the robustness of the tax effect found for the 1983 to 1989 period, and the weak instrument problem for the 1992 to 1995 period. To address both these issues we try a variety of other instruments.

First, we use a broad occupation grouping as an instrument for the tax rates. Individuals were separated into blue and white-collar occupations, with the rational being that white-collar workers are the treatment group because they have relatively more self-employment opportunities than blue-collar workers. While the white-collar occupation-year dummy interaction variable is a strong instrument in the first stage regressions for marginal tax rates in the 1983 to 1989 period, the instrument is weak in all other time periods. Results from the choice model for the 1983 to

\footnotetext{
${ }^{34}$ Results for the alternative definition of self-employment are discussed in the next section of the paper.
} 
1989 time period using the occupation-year dummy instrument show no significant tax effects. The next attempt at addressing the weak instrument problem was to use two instruments derived from the education of the household head. Education level is broken down into three categories; less than high school, high school graduate or some college, and college graduate or higher. These dummy variables, which are interacted with a year dummy, are weak instruments in all time periods. Another attempt at addressing the weak instrument problem is to use the educationyear and occupation-year interactions as the instruments for either tax rate. Combining the education and occupation instruments yields strong instruments for marginal tax rates over the 1983 to 1989 period, but the instruments are weak in all other periods. Using these instruments in the choice model for the 1983 to 1989 period yields no significant tax effects.

The final attempt at finding a strong instrument involves using an indicator of high predicted household income interacted with a year dummy. While we would like to use actual household income as the grouping variable and instrument for the tax function, the endogeneity of income and time-varying nature of income makes it an invalid instrument. To overcome these problems, income is predicted for each household in the sample using the coefficients from an income regression estimated on one year of the data. For example, we use the coefficients from an income regression using the households from the $1983 \mathrm{SCF}$ in the sample to predict income for the households in the sample from the 1989 and 1992 SCF. Households in each year are then considered in the high income group (treatment group) if their predicted income is greater than the median predicted income of all households in that year. By construction, the high income grouping variable is time-invariant, and using the predicted income amount avoids the endogeneity issue. ${ }^{35}$ Using the high predicted income indicator interacted with a year dummy yields strong instruments for both tax rates for the 1983 to 1989 period, but the instruments are weak in all other time periods. Estimates from the choice models using the predicted high income*1989 instrument show no significant tax effects over the 1983 to 1989 period.

As a further test of the validity of the grouping variables, we estimate the choice model using different pre and post intervention years. For the TRA86 sample, we alter the postintervention year to be 1992; the instruments remain strong for marginal tax rates, but the tax effects are insignificant. For the OBRA93 sample, the instruments are all still weak, whether the post-intervention year is 1998 or 2001 . Overall, altering the post intervention year causes the effect of marginal tax rates to become insignificant over the 1983 to 1989 period.

\footnotetext{
${ }^{35}$ The income regressions include education, age, region, industry, and occupation dummies, plus marital status, number of children, current job tenure, labor force experience, race, net worth, and measures of risk tolerance and credit worthiness.
} 
To check that the results are not driven by the sample selection, various modifications are made to the sample restrictions. First, we estimate the choice model on samples that exclude single household heads. The rational for this test is that single individuals may make employment decisions differently than individuals who are married or cohabitating. Results for the choice model without single individuals show no significant tax effects, even with strong instruments for the 1983 to 1989 time period. We also estimate the choice model on only single individuals, which also results in no significant tax effects. Next we drop single, married filing separately, and cohabitating households from the samples. Again, the intuition for this restriction is that these types of household make employment decisions differently than married filing jointly households. Results for the choice model using the married filing jointly samples reveal yet again no significant tax effects. While it is not surprising that altering the sample restrictions does not influence the results for the OBRA93 sample, the finding of no significant tax effects in the TRA86 sample is more evidence of the tenuous nature of those results.

A common concern in the self-employment choice literature is the possible endogeneity of the industry controls. The intuition behind this concern is that self-employment is more common in certain industries. While it is true that the self-employed are concentrated in nonmanufacturing industries, whether the self-employment and industry of work decisions are made simultaneously is debatable. For most workers, the industry choice is at least made at a different time that than the self-employment decision; workers may need to gain experience before striking out on their own. Of course, doctors and lawyers are the obvious exceptions to this reasoning. When we re-estimate our choice models without industry controls the significant effect of marginal tax rates over the 1983 to 1989 period disappears, but the effects of the rest of covariates remain unchanged. This is further evidence of the weakness of the initial findings for the TRA86 sample.

The results are also somewhat sensitive to the definition of self-employment. Partition the self-reported measure of self-employment into two sub-groups; self-employed who own an actively managed business and those who do not. Separating the self-employed based on business ownership is important if one believes that there are differences in how taxes affect each group. If we restrict the definition of self-employment to self-reported self-employed individuals who own an actively managed business, the education-year interactions are strong instruments for the 1983 to 1989 period, but yield no significant tax effects, and the weak instrument problem is present for the OBRA93 sample. Modifying the definition of self-employment to only include self-reported self-employed individuals who do not own a business yields results similar to the initial finding of a negative and significant effect of marginal tax rates over the 1983 to 1989 time 
frame. ${ }^{36}$ In addition, there is a negative and significant effect of average tax rates over the same time frame. This finding provides some evidence that the self-employed who do not own a business are more likely to be influenced by tax changes, which could be due to their weaker attachment to being self-employed. Since these self-employed individuals do not report any business assets, it may be easier for them to enter or exit self-employment than the self-employed who report owning a business. However, these results should be interpreted with caution; the tax effects are only significant when using the some college*1989 instrument.

While we show results for each tax rate entered individually into the self-employment choice equation, other studies in the literature include both tax rates into the same model. Robson and Wren (1999), Bruce (2000), Hubbard and Gentry (2000), and other studies find that when both tax rates are independent variables, marginal tax rates have a negative relationship with the self-employment rate, while average tax rates have a positive relationship. Including both tax rates in our models presents the additional challenge of finding two strong instruments to use in the first stage regressions. Using the education-year dummy interaction and the occupation-year dummy interaction together seems the obvious choice, but these instruments are only strong in the 1983 to 1989 time period. When we estimate the models using these instruments, we find no significant effects of either tax rate, and the significance of the other independent variables deteriorates considerably. The lack of strong instruments is certainly a problem for the models with two tax rates, another possible reason for the poor estimation results is the high degree of correlation between the two tax rates. The correlation is on average about .55, and significant at the one percent level. The combination of weak instruments and the high correlation between the two rates is most likely causing identification problems in the model.

The lack of any significant tax effects for the 1983 to 1989 period using any of the alternative instruments casts doubt on the robustness of the significant effect found using the some college*1989 instrument. Furthermore, the significant tax effect for the 1983 to 1989 period is sensitive to the sample composition. These two results lead us to interpret the results as evidence that TRA86 had no significant effect on the self-employment decision. In terms of 1992 to 1995 time period, one possible cause of our weak instrument problem is that OBRA93 affected only very high-income taxpayers (with taxable income greater than $\$ 165,200$, if married filing jointly). This high-income group is a very small fraction of taxpayers, and only a small fraction

\footnotetext{
${ }^{36}$ For both of the alternative definitions of self-employment, when we restrict the definition of selfemployment to one of the sub-groups, the other sub-group is dropped from the analysis, versus that group remaining in the sample and being reclassified as employees.
} 
of the treatment group (for any of the grouping variables) is above this threshold. ${ }^{37}$ Given that the SCF oversamples wealthy households, the absence of any tax effects is strong evidence of that OBRA93 also had little influence on the self-employment decision.

\section{Conclusions}

Understanding why individuals choose to become self-employed and how public policies affect this choice is an important area of research. Altering tax policies is often the mechanism by which the government attempts to influence the behavior of individuals and households. This paper examines the effects of the TRA86 and OBRA93 marginal tax rate changes on probability of an individual choosing self-employment.

The results show that neither of the two tax reforms studied had a consistently significant effect on the self-employment decision. While there is some evidence of a negative and significant effect over the 1983 to 1989 period from TRA86, the results are quite sensitive to the choice of instruments and the sample restrictions. Other covariates, such as education, industry, wealth, attitudes toward risk, and previous self-employment experience are consistently more important influences on the self-employment decision. Thus, changing marginal tax rates does not seem to be the best policy tool for promoting self-employment. Of course, other elements of the tax code may matter more than marginal tax rates, such as the capital gains tax rate or the differences between individual and corporate tax rates, but those are topics for future research.

\footnotetext{
${ }^{37}$ For example, in the 1995 SCF (1994 tax year) only 5.7 percent of households in which the head has a college degree had taxable income over the necessary threshold.
} 


\section{Appendix}

Comparison of SCF and CPS Self-Employment Rates

Table A1 presents a comparison of self-employment rates from the SCF and from the CPS Merged Outgoing Rotation group datasets. The composition of the sample from the CPS data is analogous to the SCF; only male household heads ages 25-64 who are currently working are included. We also construct cohorts in the CPS data and two samples that encompass TRA86 and OBRA93. For example, in the OBRA93 sample, when using the 1989 CPS data, we only include males ages 25-55 that are currently working.

The top panel of Table A1 reproduces the self-employment rates of the SCF from Table 2b. As noted in the data section of the paper, for the sample used in the analysis we drop selfemployed individuals who report owning a business organized as a C-corporation. The second panel in Table A1 shows the self-employment rates when we include individuals with Ccorporations; self-employment rates increase about 1.5 to 2 percentage points, regardless of the definition of self-employment. The bottom panel of Table A1 presents the self-employment rates for the CPS samples, in total and by incorporation status.

Comparing the self-reported self-employment definition from the SCF (with or without C-corporations) to the overall CPS self-employment rate, we see the time trend in the two rates is the same. Both data sources show rising rates from 1983 to 1992, a small decline between 1992 and 1995, and an increase over the 1995 to 2001 period. However, the decline between 1992 and 1995, and the rise over the 1995 to 2001 time frame are much smaller in the CPS. The selfreported and has an active business self-employment definition in the SCF (without Ccorporations) is probably best compared to the CPS self-employed, unincorporated rate. Neither the CPS or the SCF rate is consistently higher or lower, but the time trend is similar.

Overall, the self-employment rates from the SCF and CPS align fairly well, with 1983, 1998, and 2001 being the exceptions. While the difference between the total CPS rate and the self-reported SCF rate (including C-corporations) is at most one percentage point in 1989, 1992, and 1995, the difference is three percentage points in 1983and 2001 and two percentage points in 1998. Further analysis has not provided a definitive reason for the differences, but even minor changes in the survey questionnaires over time or sampling error could be the culprit. 


\section{References}

Amenyia, T. (1978) "The Estimation of a Simultaneous Equation Generalized Probit Model,: Econometrica, 46, 1193-1205.

Blanchflower, D. A. Oswald, and A. Stutzer (2001) "Latent Entrepreneurship Across Nations," European Economic Review, 45, 680-691.

Blau, D. (1987) "A Time-series Analysis of Self-employment in the United States," Journal of Political Economy, 95, 445-467.

Browning, M., A. Deaton, and M. Irish (1985) "A Profitable Approach to Labor Supply and Commodity Demands Over the Life Cycle," Econometrica, 53, 503-544.

Bruce, D. (2000) "Effects of the U. S. Tax System on Transitions into Self-employment," Labour Economics, 7, 547-575.

Bruce, D. (2001) "Taxes and Entrepreneurial Endurance: Evidence from the Self-Employed," National Tax Journal, 55, 5-24.

Bruce, D. and D. Holtz-Eakin (2001) "Taxes and the Allocation of Entrepreneurial Effort," Unpublished working paper, Department of Economics, University of Tennessee-Knoxville.

Carroll, R., D. Holtz-Eakin, M. Rider, and H. Rosen (2000a) "Income Taxes and Entrepreneurs' Use of Labor," Journal of Labor Economics, 18, 324-351.

Carroll, R., D. Holtz-Eakin, M. Rider, and H. Rosen (2000b) "Personal Income Taxes and the Growth of Small Firms," NBER Working Paper No. 7980.

Cullen, J. and R. Gordon (2002) "Taxes and Entrepreneurial Activity: Theory and Evidence for the U.S.," NBER Working Paper 9015.

Deaton, A. (1985) "Panel Data from Time Series of Cross Sections," Journal of Econometrics, 30, 109-126.

Deaton, A. (1997) The Analysis of Household Surveys: A Microeconometric Approach to Development Policy. Baltimore/London: The Johns Hopkins University Press.

Devine, T. J. (1994) "Characteristics of Self-Employed Women in the United States", Monthly Labor Review, 117, 20-34.

Domouchel, W. and G. Duncan (1983) "Using Sample Survey Weights in Multiple Regression Analyses of Stratified Samples," Journal of the American Statistical Association, 78, 535-543.

Eissa, N. (1995) "Taxation and Labor Supply of Married Women: The Tax Reform Act of 1986 as a Natural Experiment," NBER Working Paper No. 5023

Eissa, N. (1996a) “Tax Reforms and Labor Supply," Tax Policy and the Economy, 10, ed. J. Poterba. 
Eissa, N. (1996b) "Labor Supply and the Economic Recovery Act of 1981," Empirical Foundations of Household Taxation, eds. M. Feldstein and J. Poterba.

Evans, D. and B. Jovanovic (1989) "An Estimated Model of Entrepreneurial Choice Under Liquidity Constraints," Journal of Political Economy, 97, 808-827.

Fairlie, R. and B. Meyer (1998) "Trends in Self-employment Among White and Black Men: 1910-1990," NBER Working Paper No. 7182.

Feenberg, D. and E. Coutts (1993) "An Introduction to the TAXSIM Model," Journal of Policy Analysis and Management, 12, 189-194.

Feenberg, D. and J. Poterba (1993) "Income Inequality and the Incomes of Very High Income Taxpayers," Tax Policy and the Economy, 7, ed. J. Poterba.

Feenberg, D. and J. Poterba. (2000) "The Income and Tax Share of Very High-Income Households, 1960-1995," American Economic Review, 90, 264-270.

Feldstein, M. (1995) "The Effect of Marginal Tax Rates on Taxable Income: A Study of the 1986 Tax Reform Act," Journal of Political Economy, 103, 551-572.

Feldstein, M. and D. Feenberg (1996) "The Effect of Increased Tax Rates on Taxable Income and Economic Efficiency: A Preliminary Analysis of the 1993 Tax Rate Increases," Tax Policy and the Economy, 10, ed. J. Poterba.

Feldstein, M. and A. Samwick. (1992) "Social Security Rules and Marginal Tax Rates", National Tax Journal, 45, 1-22.

Gentry, W. and R. Hubbard (2000) "Tax Policy and Entrepreneurial Entry," Working Paper, Columbia University.

Georgellis, Y. and H. Wall (2002) "Entrepreneurship and the Policy Environment," Federal Reserve Bank of St. Louis Research Division Working Paper No. 2002-019A.

Goode, R. (1949) "The Income Tax and the Supply of Labor," Journal of Political Economy, 1, 428-437.

Goolsbee, A. (2000). “It's Not About the Money: Why Natural Experiments Don't Work on the Rich," in Does Atlas Shrug? The Economic Consequences of Taxing the Rich, ed. J. Slemrod, New York: The Russell Sage Foundation, Cambridge and London: The Harvard University Press.

Gordon, R. and J. Slemrod (2000) “Are Real Responses to Taxes Simply Income Shifting between Corporate and Personal Tax Bases?" In J. Slemrod (eds) Does Atlas Shrug? The Economic Consequences of Taxing the Rich, Russell Sage Foundation and Harvard University Press: Cambridge.

Gruber, J. and E. Saez (2000) "The Elasticity of Taxable Income: Evidence and Implications," NBER Working Paper 7512. 
Heckman, J. (1996) "Labor Supply and the Economic Recovery Act of 1981: A Comment," Empirical Foundations of Household Taxation, NBER Research Project Report, Chicago and London: University of Chicago Press, 32-38.

Hurst, E. and A. Lusardi (2003) "Liquidity Constraints, Household Wealth and Entrepreneurship," forthcoming Journal of Political Economy.

IRS Statistics of Income Individual Tax Returns (1982, 1988, 1991, 1994, 1997) Internal Revenue Service, Washington, DC.

Kanbur, S. (1979) "Of Risk Taking and the Personal Distribution of Income," Journal of Political Economy, 87, 769-797.

Kennickell, A. (1991) "Imputation of the 1989 Survey of Consumer Finances: Stochastic Relaxation and Multiple Imputation," 1991 Proceedings of the Section on Survey Research Methods, Annual Meetings of the American Statistical Association, Atlanta, GA.

Kennickell, A. (1998a) "List Sample Design for the 1998 Survey of Consumer Finances," working paper, Board of Governors of the Federal Reserve System.

Kennickell, A. (1998b) "Multiple Imputation in the Survey of Consumer Finances," Proceedings of the Section on Business and Economic Statistics, 1998 Annual Meetings of the American Statistical Association, Dallas, TX.

Kennickell, A. (1999) "Revisions to the SCF Weighting Methodology: Accounting for Race/Ethnicity and Homeownership," working paper, Board of Governors of the Federal Reserve System.

Kennickell, A. and R. Woodburn (1999) "Consistent Weight Design for the 1989, 1992, and 1995 SCFs, and the Distribution of Wealth," Review of Income and Wealth, Series 45, 2, 193-215.

Kihlstrom, R. and J.-J. Laffont (1983) "Taxation and Risk Taking in general Equilibrium Models with Free Entry," Journal of Public Economics, 21, 159-181.

Knight, F. (1921) Risk, Uncertainty, and Profit. Chicago/London: The University of Chicago Press.

Le, Anh. (1999) "Empirical Studies of Self-Employment”, Journal of Economic Surveys, 13, 381416.

Lindsey, L. (1987) "Individual Taxpayer Response to Tax Cuts; 1982-1984 with Implications for the Revenue Maximizing Tax Rate,” Journal of Public Economics, 33, 173-206.

Long, J. (1982a) "Income Taxation and the Allocation of Market Labor," Journal of Labor Research, 3, 259-276.

Long, J. (1982b) "The Income Tax and Self-Employment," National Tax Journal, 35, 31-42.

Meyer, B. (1995) "Natural and Quasi-Experiments in Economics," Journal of Business and Economic Statistics, 13, 151-161. 
Moffitt, R.(1993) "Identification and Estimation of Dynamic Models with a Time Series of Repeated Cross-Sections," Journal of Econometrics, 59, 99-123.

Moffitt, R. and M. Wilhelm (2000) " Taxation and Labor Supply Decisions of the Affluent," In J. Slemrod (eds) Does Atlas Shrug? The Economic Consequences of Taxing the Rich, Russell Sage Foundation and Harvard University Press: Cambridge.

Moore, R. (1983) "Self-employment and the Incidence of the Payroll Tax," National Tax Journal, 36, 491-501.

Navratil, J. (1995) "The Economic Recovery Tax Act of 1981: Evidence on Individual Taxpayer Behavior from Panel Tax Return Data," Unpublished Harvard Thesis.

Newey, W. (1987) "Efficient Estimation of Limited Dependent Variable Models with Endogenous Explanatory Variables," Journal of Econometrics, 36, 231-250.

Nijman, T. and M. Verbeek (1990) "Estimation of Time-Dependent Parameters in Linear Models Using Cross-Sections, Panels, or Both," Journal of Econometrics, 46, 333-346.

Nijman, T. and M. Verbeek (1992) "Can Cohort Data Be Treated as Genuine Panel Data?" Empirical Economics, 17, 9-23.

Parker, S. (1996) "A Time Series Model of Self-employment Under Uncertainty," Economica, 63, 459-475.

Petska, T. (1998) "Taxes and Business Organizational Choice: Deja Vu All Over Again?" Internal Revenue Service, SOI Research Paper.

Robson, M. and C. Wren (1999) "Marginal and Average Tax Rates and the Incentive for SelfEmployment," Southern Economic Journal, 65, 757-773.

Schuetze, H. (1998) "Taxes, Economic Conditions, and Recent Trends in Male Self-employment: A Canada-US Comparison," Working Paper, McMaster University.

Sheshinski, E. and J. Dreze (1976) "Demand Fluctuations, Capacity Utilization, and Costs," American Economic Review, 66, 731-742.

Slemrod, J., M. Blumenthal, and C. Christian (2001) "Taxpayer Response to an Increased Probability of Audit: Evidence from a Controlled Experiment in Minnesota," Journal of Public Economics, 79, 455-483.

Stock, J. and M. Yogo (2002) “Testing for Weak Instruments in Linear IV Regression,' NBER Technical Working Paper No. 284.

Stock, J., J. Wright, and M. Yogo (2002) "A Survey of Weak Instruments and Weak Identification in Generalized Method of Moments," Journal of Business and Economic Statistics, 20, 518-529. 


\section{Table 1}

Tax Brackets for Married Filing Jointly Taxpayers

(all dollar values in 2001 dollars, adjusted by the CPI-RS)

\begin{tabular}{|cc|cc|cc|cc|}
\hline $\mathbf{1 9 8 2}$ & $\begin{array}{c}\text { Min } \\
\text { Rates }\end{array}$ & $\begin{array}{c}\mathbf{1 9 8 8} \\
\text { Taxable Inc }\end{array}$ & $\begin{array}{c}\text { Min } \\
\text { Rates }\end{array}$ & $\begin{array}{c}\mathbf{1 9 9 1} \\
\text { Taxable Inc } \\
\text { Rates }\end{array}$ & $\begin{array}{c}\text { Min } \\
\text { Taxable Inc }\end{array}$ & $\begin{array}{c}\mathbf{1 9 9 4} \\
\text { Rates }\end{array}$ & $\begin{array}{c}\text { Min } \\
\text { Taxable Inc }\end{array}$ \\
\hline 12 & $\$ 5,984$ & 15 & $\$ 0$ & 15 & $\$ 0$ & 15 & $\$ 0$ \\
14 & $\$ 9,680$ & 28 & $\$ 42,840$ & 28 & $\$ 43,180$ & 28 & $\$ 44,840$ \\
16 & $\$ 13,376$ & 33 & $\$ 103,536$ & 31 & $\$ 104,331$ & 31 & $\$ 108,383$ \\
19 & $\$ 20,944$ & 28 & $\$ 223,875$ & & & 36 & $\$ 165,200$ \\
22 & $\$ 28,160$ & & & & & 39.6 & $\$ 295,000$ \\
25 & $\$ 35,552$ & $\mathbf{1 9 9 7}$ & Min & $\mathbf{2 0 0 0}$ & Min & & \\
29 & $\$ 43,296$ & Rates & Taxable Inc & Rates & Taxable Inc & & \\
33 & $\$ 52,624$ & 15 & $\$ 0$ & 15 & $\$ 0$ & & \\
39 & $\$ 61,952$ & 28 & $\$ 45,320$ & 28 & $\$ 45,166$ & & \\
44 & $\$ 80,608$ & 31 & $\$ 109,560$ & 31 & $\$ 109,129$ & & \\
49 & $\$ 105,600$ & 36 & $\$ 166,925$ & 36 & $\$ 166,294$ & & \\
50 & $\$ 150,656$ & 39.6 & $\$ 298,155$ & 39.6 & $\$ 297,001$ & & \\
\cline { 5 - 6 } & & & & &
\end{tabular}




\section{Table 2a}

\section{Percent of Households in Various Demographic Groups}

1983, 1989, 1992, 1995, 1998, and 2001 SCF

(for male household heads ages 25-64 who are currently working)

\begin{tabular}{|l|rrr|rrrr|}
\hline & \multicolumn{3}{|c|}{ TRA86 Sample } & \multicolumn{5}{c|}{ OBRA93 Sample } \\
Year & $\mathbf{1 9 8 3}$ & $\mathbf{1 9 8 9}$ & $\mathbf{1 9 9 2}$ & $\mathbf{1 9 9 2}$ & $\mathbf{1 9 9 5}$ & $\mathbf{1 9 9 8}$ & $\mathbf{2 0 0 1}$ \\
\hline Education Definition 1 & & & & & & & \\
$\quad$ Some college or higher & 50.0 & 55.7 & 60.8 & 59.9 & 58.4 & 59.8 & 60.2 \\
& & 2.1 & 1.5 & 1.5 & 1.4 & 1.6 & 1.4 \\
\hline Education Definition 2 & & & & & & & \\
College or higher & 32.7 & 37.2 & 42.4 & 41.0 & 39.1 & 39.7 & 43.7 \\
& & 1.6 & 1.4 & 1.3 & 1.2 & 1.3 & 1.4 \\
\hline
\end{tabular}

Notes: All estimates are weighted by the sample weights, standard errors in italics 
Table 2b

Self-Employment Rates by Year and by Group

1983, 1989, 1992, 1995, 1998, and 2001 SCF

(for male household heads ages 25-64 who are currently working)

\begin{tabular}{|c|c|c|c|c|c|c|c|}
\hline \multirow[b]{2}{*}{ Year } & \multicolumn{3}{|c|}{ TRA86 Sample } & \multirow[b]{2}{*}{1992} & \multicolumn{3}{|c|}{ OBRA93 Sample } \\
\hline & 1983 & 1989 & 1992 & & 1995 & 1998 & 2001 \\
\hline \multicolumn{8}{|l|}{ Self-employment definition } \\
\hline \multirow[t]{2}{*}{ Self-reported SE } & 11.4 & 16.6 & 18.6 & 15.1 & 14.5 & 17.0 & 17.7 \\
\hline & & 1.3 & 0.9 & 0.7 & 0.7 & 0.8 & 0.7 \\
\hline \multirow{2}{*}{$\begin{array}{l}\text { Self-reported SE and } \\
\text { has an active business }\end{array}$} & 7.4 & 11.6 & 14.1 & 11.2 & 9.8 & 12.1 & 12.7 \\
\hline & & 1.1 & 0.8 & 0.7 & 0.6 & 0.7 & 0.6 \\
\hline \multicolumn{8}{|l|}{$\begin{array}{r}\text { Education Definition 1 } \\
\text { Self-reported SE }\end{array}$} \\
\hline \multirow[t]{2}{*}{ High school or less } & 11.5 & 14.6 & 16.4 & 13.4 & 13.4 & 14.3 & 15.0 \\
\hline & & 1.5 & 1.4 & 1.4 & 1.0 & 1.3 & 1.3 \\
\hline \multirow[t]{2}{*}{ Some college or higher } & 11.4 & 18.3 & 20.0 & 16.3 & 15.3 & 18.9 & 19.4 \\
\hline & & 1.7 & 1.2 & 1.0 & 0.8 & 0.9 & 1.0 \\
\hline \multicolumn{8}{|l|}{ Self-reported SE / business } \\
\hline \multirow[t]{2}{*}{ High school or less } & 7.3 & 10.7 & 12.5 & 9.5 & 8.8 & 9.8 & 9.7 \\
\hline & & 1.5 & 1.3 & 1.2 & 0.9 & 1.0 & 1.0 \\
\hline \multirow[t]{2}{*}{ Some college or higher } & 7.5 & 12.3 & 15.2 & 12.5 & 10.6 & 13.6 & 14.6 \\
\hline & & 1.2 & 1.0 & 0.9 & 0.8 & 0.9 & 0.8 \\
\hline \multirow{2}{*}{\multicolumn{8}{|c|}{$\begin{array}{r}\text { Education Definition } 2 \\
\text { Self-reported SE }\end{array}$}} \\
\hline & & & & & & & \\
\hline \multirow[t]{2}{*}{ Some college or less } & 11.6 & 16.2 & 15.9 & 13.2 & 14.2 & 16.2 & 15.8 \\
\hline & & 1.6 & 1.1 & 1.0 & 0.8 & 1.1 & 1.0 \\
\hline \multirow[t]{2}{*}{ College or higher } & 11.0 & 17.5 & 22.2 & 17.9 & 14.9 & 18.3 & 20.1 \\
\hline & & 1.9 & 1.5 & 1.4 & 1.1 & 1.1 & 1.1 \\
\hline \multirow{3}{*}{$\begin{array}{r}\text { Self-reported SE / business } \\
\text { Some college or less }\end{array}$} & & & & & & & \\
\hline & 7.6 & 10.8 & 12.4 & 9.8 & 9.4 & 11.8 & 10.8 \\
\hline & & 1.3 & 1.0 & 0.9 & 0.7 & 0.9 & 0.8 \\
\hline \multirow[t]{2}{*}{ College or higher } & 7.1 & 12.8 & 16.6 & 13.4 & 10.5 & 12.5 & 15.0 \\
\hline & & 1.5 & 1.2 & 1.2 & 0.9 & 1.0 & 0.9 \\
\hline
\end{tabular}

ple weights, standard errors in italics 


\section{Table 3}

Marginal and Average Tax Rates by Year and by Group,

1983, 1989, 1992, 1995, 1998, and 2001 SCF

(for male household heads ages 25-64 who are currently working)

\begin{tabular}{|c|c|c|c|c|c|c|c|c|}
\hline \multirow[b]{2}{*}{ Year } & & \multicolumn{3}{|c|}{ TRA86 Sample } & \multicolumn{4}{|c|}{ OBRA93 Sample } \\
\hline & & 1983 & 1989 & 1992 & 1992 & 1995 & 1998 & 2001 \\
\hline \multirow[t]{4}{*}{ All Households } & MTR & 42.1 & 36 & 37.3 & 37.1 & 37.3 & 38.1 & 39.3 \\
\hline & & & 0.8 & 0.5 & 0.5 & 0.5 & 0.6 & 0.6 \\
\hline & ATR & 29.3 & 28.2 & 28.9 & 28.2 & 27.8 & 28.6 & 28.9 \\
\hline & & & 0.6 & 0.4 & 0.4 & 0.4 & 0.5 & 0.4 \\
\hline \multirow{5}{*}{$\begin{array}{r}\text { Education Definition } 1 \\
\text { High school or less }\end{array}$} & & & & & & & & \\
\hline & MTR & 39.8 & 35.2 & 35.4 & 35.1 & 35.5 & 36.8 & 36.7 \\
\hline & & & 0.5 & 0.5 & 0.4 & 0.6 & 0.5 & 0.5 \\
\hline & ATR & 27.3 & 26.8 & 26.6 & 25.9 & 26.0 & 26.9 & 26.3 \\
\hline & & & 0.3 & 0.3 & 0.3 & 0.3 & 0.2 & 0.2 \\
\hline \multirow[t]{4}{*}{ Some college or higher } & MTR & 44.5 & 36.7 & 38.6 & 38.4 & 38.6 & 38.9 & 41.1 \\
\hline & & & 0.4 & 0.3 & 0.3 & 0.3 & 0.3 & 0.3 \\
\hline & ATR & 31.2 & 29.2 & 30.4 & 29.7 & 29.0 & 29.8 & 30.6 \\
\hline & & & 0.2 & 0.2 & 0.2 & 0.2 & 0.2 & 0.2 \\
\hline \multirow{5}{*}{$\begin{array}{r}\text { Education Definition } 2 \\
\text { Some college or less }\end{array}$} & & & & & & & & \\
\hline & MTR & 40.7 & 35.1 & 36.6 & 36.2 & 36.2 & 36.8 & 37.5 \\
\hline & & & 0.5 & 0.4 & 0.3 & 0.4 & 0.3 & 0.4 \\
\hline & ATR & 28.0 & 27.2 & 27.5 & 26.8 & 26.7 & 27.3 & 27.0 \\
\hline & & & 0.3 & 0.2 & 0.2 & 0.2 & 0.2 & 0.2 \\
\hline \multirow[t]{4}{*}{ College or higher } & MTR & 45.1 & 37.5 & 38.3 & 38.3 & 39.0 & 40.0 & 41.6 \\
\hline & & & 0.4 & 0.3 & 0.3 & 0.4 & 0.3 & 0.3 \\
\hline & ATR & 32.0 & 29.8 & 30.9 & 30.2 & 29.4 & 30.7 & 31.3 \\
\hline & & & 0.3 & 0.3 & 0.2 & 0.2 & 0.2 & 0.3 \\
\hline
\end{tabular}

Notes: All estimates are weighted by the sample weights, standard errors in italics, both the MTR and ATR include the payroll tax 
Table 4a

Means of Various Characteristics for the TRA86 Sample, 1983, 1989, and 1992 SCF

(for male household heads ages 25-64 who are currently working)

Self-reported self-employment measure

\begin{tabular}{|c|c|c|c|c|c|c|}
\hline \multirow{3}{*}{\begin{tabular}{|l|} 
\\
Variable \\
\end{tabular}} & \multicolumn{6}{|c|}{ TRA86 Sample } \\
\hline & \multicolumn{2}{|c|}{1983} & \multicolumn{2}{|c|}{1989} & \multicolumn{2}{|c|}{1992} \\
\hline & Emp & SE & Emp & SE & Emp & SE \\
\hline \multirow[t]{2}{*}{ Total MTR } & 42.9 & 36.5 & 37.2 & 30.0 & 37.8 & 35.4 \\
\hline & (9.4) & $(13.5)$ & $(8.7)$ & $(15.0)$ & $(10.0)$ & $(12.6)$ \\
\hline \multirow[t]{2}{*}{ Total ATR } & 29.9 & 24.4 & 28.6 & 26.1 & 28.9 & 29.0 \\
\hline & $(7.3)$ & $(9.1)$ & $(6.0)$ & $(7.8)$ & $(6.8)$ & $(8.5)$ \\
\hline \multirow[t]{2}{*}{ Head's earnings } & 44,893 & 47,964 & 50,995 & 74,655 & 47,439 & 70,661 \\
\hline & $(52,271)$ & $(79,381)$ & $(61,039)$ & $(134,010)$ & $(82,199)$ & $(169,714)$ \\
\hline \multirow[t]{2}{*}{ Spouse / partner's earnings } & 10,672 & 8,698 & 15,202 & 14,760 & 15,305 & 18,971 \\
\hline & $(14,432)$ & $(14,085)$ & $(23,419)$ & $(25,348)$ & $(20,384)$ & $(36,164)$ \\
\hline Spouse / partner works & 0.51 & 0.41 & 0.61 & 0.55 & 0.59 & 0.60 \\
\hline \multirow[t]{2}{*}{$\mathrm{HH}$ income } & 63,206 & 64,749 & 72,145 & 122,263 & 70,257 & 103,420 \\
\hline & $(74,111)$ & $(84,423)$ & $(130,417)$ & $(322,368)$ & $(117,531)$ & $(228,100)$ \\
\hline \multirow[t]{2}{*}{ HH net worth } & 169,412 & 337,361 & 209,272 & 818,289 & 219,522 & 724,348 \\
\hline & $(1,108,673)$ & $(1,073,885)$ & $(840,979)$ & $(2,769,242)$ & $(1,077,093)$ & $(2,676,858)$ \\
\hline \multirow[t]{2}{*}{ Value of active business(es) } & 31,359 & 138,884 & 12,494 & 227,931 & 17,353 & 232,777 \\
\hline & $(471,810)$ & $(726,457)$ & $(151,737)$ & $(1,068,458)$ & $(417,136)$ & $(1,539,678)$ \\
\hline \multirow[t]{2}{*}{ Value of primary residence } & 85,102 & 119,401 & 121,774 & 179,537 & 109,168 & 177,833 \\
\hline & $(113,717)$ & $(128,887)$ & $(161,951)$ & $(295,352)$ & $(138,959)$ & $(265,230)$ \\
\hline Less than high school & 0.16 & 0.15 & 0.14 & 0.15 & 0.12 & 0.09 \\
\hline High school diploma & 0.34 & 0.35 & 0.32 & 0.24 & 0.28 & 0.26 \\
\hline Some college & 0.17 & 0.18 & 0.18 & 0.22 & 0.19 & 0.15 \\
\hline College or higher & 0.33 & 0.32 & 0.37 & 0.39 & 0.40 & 0.51 \\
\hline Pincome $>$ median Pincome & 0.48 & 0.68 & 0.47 & 0.66 & 0.47 & 0.64 \\
\hline Head's tenure at current job & 9.2 & 10.6 & 10.6 & 12.2 & 11.0 & 13.4 \\
\hline Head's experience & 19.1 & 21.3 & 23.3 & 25.7 & 25.9 & 26.2 \\
\hline Prior job self-employment & 0.05 & 0.07 & 0.04 & 0.12 & 0.04 & 0.14 \\
\hline Head's weekly hours & 43.3 & 49.5 & 44.9 & 49.6 & 43.8 & 52.0 \\
\hline Head's weeks per year & 51.2 & 49.9 & 50.8 & 49.8 & 50.2 & 50.4 \\
\hline Head's age & 38.3 & 40.5 & 42.6 & 45.2 & 45.4 & 46.4 \\
\hline Age 55-64 in 1983 & 0.02 & 0.03 & 0.01 & 0.04 & 0.01 & 0.01 \\
\hline Age $45-54$ in 1983 & 0.25 & 0.35 & 0.21 & 0.27 & 0.19 & 0.22 \\
\hline Age $35-44$ in 1983 & 0.34 & 0.32 & 0.30 & 0.35 & 0.34 & 0.33 \\
\hline Age $25-34$ in 1983 & 0.39 & 0.29 & 0.48 & 0.35 & 0.46 & 0.44 \\
\hline
\end{tabular}




\begin{tabular}{|c|c|c|c|c|c|c|}
\hline \multirow[b]{2}{*}{ Year } & \multicolumn{6}{|c|}{ TRA86 Sample } \\
\hline & \multicolumn{2}{|c|}{1983} & \multicolumn{2}{|c|}{1989} & \multicolumn{2}{|c|}{1992} \\
\hline Variable & Emp & SE & Emp & SE & Emp & SE \\
\hline Head is white & 0.85 & 0.94 & 0.78 & 0.80 & 0.78 & 0.84 \\
\hline Head is married / lwp & 0.85 & 0.89 & 0.88 & 0.84 & 0.85 & 0.83 \\
\hline \# of children under 18 & 1.21 & 1.23 & 1.18 & 1.11 & 1.02 & 0.88 \\
\hline Head in poor health & 0.01 & 0.01 & 0.02 & 0.02 & 0.01 & 0.01 \\
\hline High risk taker & 0.18 & 0.28 & 0.16 & 0.19 & 0.18 & 0.29 \\
\hline Average risk taker & 0.44 & 0.49 & 0.47 & 0.53 & 0.44 & 0.44 \\
\hline No risks & 0.36 & 0.24 & 0.37 & 0.29 & 0.38 & 0.28 \\
\hline Turn down for credit & 0.15 & 0.16 & 0.18 & 0.24 & 0.20 & 0.22 \\
\hline Problems making payments & 0.16 & 0.13 & 0.18 & 0.26 & 0.13 & 0.16 \\
\hline Northeast & 0.22 & 0.25 & 0.22 & 0.17 & 0.23 & 0.22 \\
\hline Northcentral & 0.34 & 0.35 & 0.31 & 0.32 & 0.25 & 0.27 \\
\hline South & 0.26 & 0.21 & 0.24 & 0.23 & 0.34 & 0.29 \\
\hline West & 0.18 & 0.19 & 0.22 & 0.27 & 0.18 & 0.22 \\
\hline Ag / Mining / Construction & 0.13 & 0.36 & 0.13 & 0.32 & 0.10 & 0.20 \\
\hline Manufacturing & 0.29 & 0.07 & 0.29 & 0.04 & 0.28 & 0.10 \\
\hline Wholesale / Retail & 0.14 & 0.16 & 0.14 & 0.15 & 0.12 & 0.17 \\
\hline FIRE / Bus / Repair & 0.08 & 0.23 & 0.09 & 0.19 & 0.10 & 0.24 \\
\hline Other industries & 0.36 & 0.18 & 0.35 & 0.30 & 0.41 & 0.28 \\
\hline Manager / Professional & 0.30 & 0.51 & 0.34 & 0.44 & 0.32 & 0.47 \\
\hline Technical / Sales & 0.15 & 0.11 & 0.16 & 0.21 & 0.22 & 0.21 \\
\hline Services & 0.07 & 0.02 & 0.07 & 0.00 & 0.09 & 0.02 \\
\hline Prod / Craft / Repair & 0.22 & 0.15 & 0.22 & 0.21 & 0.14 & 0.14 \\
\hline Operators / Laborers & 0.22 & 0.04 & 0.18 & 0.04 & 0.20 & 0.10 \\
\hline Farm / Forest / Fishery & 0.02 & 0.16 & 0.02 & 0.09 & 0.02 & 0.05 \\
\hline State unemployment rate & 9.73 & 9.56 & 5.33 & 5.30 & 7.47 & 7.77 \\
\hline Expect inheritance & 0.19 & 0.24 & 0.27 & 0.28 & 0.19 & 0.25 \\
\hline Partnership & 0.02 & 0.21 & 0.03 & 0.13 & 0.02 & 0.16 \\
\hline Sole proprietor & 0.03 & 0.44 & 0.05 & 0.45 & 0.06 & 0.48 \\
\hline S corporation & NA & NA & 0.01 & 0.11 & 0.01 & 0.11 \\
\hline Other business type & NA & NA & 0.00 & 0.01 & 0.00 & 0.01 \\
\hline Full-time worker & 0.97 & 0.91 & 0.97 & 0.89 & 0.95 & 0.93 \\
\hline Work 80 hrs + a week & 0.01 & 0.04 & 0.01 & 0.06 & 0.01 & 0.09 \\
\hline Number of Observations & 1416 & 200 & 972 & 420 & 964 & 617 \\
\hline
\end{tabular}

Other industries includes transportation, communications, personal services, entertainment, professional services, and public administration

Notes: All estimates are weighted by the sample weights, standard deviations in parentheses, dollar values in 2001 dollars 
Table 4b

Means of Various Characteristics for the OBRA93 Sample, 1992, 1995, 1998, and 2001 SCF

(for male household heads ages 25-64 who are currently working)

Self-reported self-employment measure

\begin{tabular}{|c|c|c|c|c|c|c|c|c|}
\hline \multirow{3}{*}{\begin{tabular}{|l|} 
\\
\end{tabular}} & \multicolumn{8}{|c|}{ OBRA93 Sample } \\
\hline & \multicolumn{2}{|c|}{1992} & \multicolumn{2}{|c|}{1995} & \multicolumn{2}{|c|}{1998} & \multicolumn{2}{|c|}{2001} \\
\hline & Emp & SE & Emp & SE & Emp & SE & Emp & SE \\
\hline \multirow[t]{2}{*}{ Total MTR } & 37.6 & 34.4 & 38.2 & 32.2 & 38.7 & 34.9 & 39.8 & 36.8 \\
\hline & $(10.1)$ & $(13.6)$ & $(10.6)$ & $(15.6)$ & $(9.8)$ & $(15.1)$ & $(10.9)$ & $(15.7)$ \\
\hline \multirow[t]{2}{*}{ Total ATR } & 28.2 & 27.9 & 28.0 & 26.2 & 28.8 & 27.7 & 29.1 & 27.8 \\
\hline & $(6.6)$ & $(8.9)$ & $(6.4)$ & $(9.2)$ & $(6.1)$ & $(9.6)$ & $(7.0)$ & $(10.6)$ \\
\hline \multirow[t]{2}{*}{ Head's earnings } & 43,295 & 65,864 & 47,678 & 74,222 & 51,315 & 81,251 & 57,168 & 98,684 \\
\hline & $(69,864)$ & $(161,301)$ & $(76,387)$ & $(202,629)$ & $(67,850)$ & $(241,614)$ & $(98,250)$ & $(262,427)$ \\
\hline \multirow[t]{2}{*}{ Spouse / partner's earnings } & 14,731 & 15,884 & 16,018 & 17,532 & 15,812 & 20,742 & 20,400 & 25,075 \\
\hline & $(19,574)$ & $(26,288)$ & $(27,717)$ & $(43,085)$ & $(28,392)$ & $(38,798)$ & $(29,393)$ & $(58,978)$ \\
\hline Spouse / partner works & 0.59 & 0.56 & 0.60 & 0.57 & 0.56 & 0.65 & 0.61 & 0.63 \\
\hline \multirow[t]{2}{*}{$\mathrm{HH}$ income } & 60,807 & 92,241 & 68,482 & 97,896 & 73,797 & 124,722 & 93,852 & 166,214 \\
\hline & $(89,721)$ & $(174,543)$ & $(112,481)$ & $(259,046)$ & $(127,390)$ & $(852,402)$ & $(293,256)$ & $(479,845)$ \\
\hline \multirow[t]{2}{*}{ HH net worth } & 144,351 & 558,914 & 173,552 & 719,882 & 245,325 & 863,413 & 332,267 & $1,297,540$ \\
\hline & $(702,421)$ & $(2,156,706)$ & $(763,678)$ & $(3,146,054)$ & $(1,128,579)$ & $(4,845,040)$ & $(1,224,506)$ & $(4,546,255)$ \\
\hline \multirow[t]{2}{*}{ Value of active business(es) } & 10,983 & 190,277 & 11,492 & 309,361 & 15,029 & 333,076 & 23,794 & 479,491 \\
\hline & $(314,916)$ & $(1,190,701)$ & $(327,380)$ & $(1,804,663)$ & $(343,137)$ & $(3,682,092)$ & $(471,667)$ & $(2,893,042)$ \\
\hline \multirow[t]{2}{*}{ Value of primary residence } & 87,740 & 162,247 & 98,220 & 153,637 & 115,404 & 200,626 & 142,778 & 288,285 \\
\hline & $(124,215)$ & $(255,135)$ & $(117,348)$ & $(274,025)$ & $(142,181)$ & $(307,159)$ & $(200,857)$ & $(446,915)$ \\
\hline Less than high school & 0.10 & 0.07 & 0.10 & 0.11 & 0.10 & 0.11 & 0.09 & 0.09 \\
\hline High school diploma & 0.31 & 0.29 & 0.32 & 0.28 & 0.32 & 0.23 & 0.32 & 0.25 \\
\hline Some college & 0.19 & 0.16 & 0.19 & 0.21 & 0.19 & 0.24 & 0.16 & 0.17 \\
\hline College or higher & 0.40 & 0.48 & 0.39 & 0.40 & 0.39 & 0.43 & 0.42 & 0.50 \\
\hline Pincome $>$ median Pincome & 0.50 & 0.50 & 0.50 & 0.50 & 0.50 & 0.50 & 0.50 & 0.50 \\
\hline Head's tenure at current job & 8.3 & 9.6 & 9.0 & 10.7 & 10.2 & 11.8 & 11.0 & 16.3 \\
\hline Head's experience & 19.0 & 20.1 & 21.3 & 23.2 & 24.1 & 25.7 & 26.4 & 29.1 \\
\hline Prior job self-employment & 0.03 & 0.12 & 0.03 & 0.14 & 0.04 & 0.08 & 0.04 & 0.09 \\
\hline Head's weekly hours & 44.1 & 52.4 & 45.6 & 50.4 & 44.8 & 49.1 & 44.4 & 45.6 \\
\hline Head's weeks per year & 50.4 & 49.4 & 50.6 & 50.2 & 50.8 & 50.0 & 50.6 & 49.1 \\
\hline Head's age & 38.7 & 40.3 & 40.9 & 42.9 & 43.6 & 45.6 & 46.1 & 49.1 \\
\hline Age 55-64 in 1992 & 0.02 & 0.00 & 0.02 & 0.01 & 0.01 & 0.01 & 0.01 & 0.02 \\
\hline Age 45-54 in 1992 & 0.26 & 0.30 & 0.21 & 0.29 & 0.22 & 0.30 & 0.19 & 0.33 \\
\hline Age $35-44$ in 1992 & 0.36 & 0.43 & 0.38 & 0.42 & 0.38 & 0.37 & 0.37 & 0.35 \\
\hline Age $25-34$ in 1992 & 0.37 & 0.27 & 0.38 & 0.29 & 0.39 & 0.32 & 0.43 & 0.31 \\
\hline
\end{tabular}




\begin{tabular}{|c|c|c|c|c|c|c|c|c|}
\hline \multirow{3}{*}{\begin{tabular}{|l|} 
\\
Variable \\
\end{tabular}} & \multicolumn{6}{|c|}{ OBRA93 Sample } & \multirow{2}{*}{\multicolumn{2}{|c|}{2001}} \\
\hline & \multicolumn{2}{|c|}{1992} & \multicolumn{2}{|c|}{1995} & \multicolumn{2}{|c|}{1998} & & \\
\hline & Emp & SE & Emp & SE & Emp & SE & Emp & $\mathbf{S E}$ \\
\hline Head is white & 0.77 & 0.83 & 0.80 & 0.88 & 0.79 & 0.89 & 0.78 & 0.88 \\
\hline Head is married / lwp & 0.82 & 0.78 & 0.84 & 0.82 & 0.83 & 0.87 & 0.84 & 0.89 \\
\hline$\#$ of children under 18 & 1.11 & 1.04 & 1.11 & 1.12 & 1.08 & 1.02 & 0.99 & 0.87 \\
\hline Head in poor health & 0.01 & 0.01 & 0.01 & 0.03 & 0.01 & 0.01 & 0.02 & 0.02 \\
\hline High risk taker & 0.19 & 0.28 & 0.21 & 0.27 & 0.30 & 0.28 & 0.28 & 0.30 \\
\hline Average risk taker & 0.44 & 0.46 & 0.44 & 0.47 & 0.42 & 0.49 & 0.43 & 0.41 \\
\hline No risks & 0.38 & 0.26 & 0.35 & 0.26 & 0.28 & 0.23 & 0.29 & 0.28 \\
\hline Turn down for credit & 0.24 & 0.26 & 0.22 & 0.22 & 0.21 & 0.20 & 0.17 & 0.13 \\
\hline Problems making payments & 0.15 & 0.18 & 0.20 & 0.22 & 0.17 & 0.16 & 0.15 & 0.11 \\
\hline Northeast & 0.21 & 0.22 & 0.19 & 0.19 & 0.19 & 0.19 & 0.20 & 0.17 \\
\hline Northcentral & 0.25 & 0.21 & 0.26 & 0.19 & 0.23 & 0.24 & 0.25 & 0.22 \\
\hline South & 0.35 & 0.29 & 0.34 & 0.38 & 0.34 & 0.37 & 0.35 & 0.38 \\
\hline West & 0.19 & 0.28 & 0.21 & 0.24 & 0.23 & 0.21 & 0.21 & 0.23 \\
\hline Ag / Mining / Construction & 0.09 & 0.24 & 0.10 & 0.30 & 0.11 & 0.32 & 0.12 & 0.25 \\
\hline Manufacturing & 0.27 & 0.11 & 0.27 & 0.13 & 0.27 & 0.07 & 0.25 & 0.05 \\
\hline Wholesale / Retail & 0.15 & 0.16 & 0.15 & 0.16 & 0.12 & 0.14 & 0.14 & 0.09 \\
\hline FIRE / Bus / Repair & 0.12 & 0.22 & 0.10 & 0.18 & 0.12 & 0.19 & 0.14 & 0.31 \\
\hline Other industries & 0.38 & 0.27 & 0.38 & 0.24 & 0.38 & 0.28 & 0.36 & 0.29 \\
\hline Manager / Professional & 0.31 & 0.45 & 0.27 & 0.37 & 0.34 & 0.40 & 0.34 & 0.65 \\
\hline Technical / Sales & 0.24 & 0.19 & 0.23 & 0.17 & 0.15 & 0.16 & 0.16 & 0.14 \\
\hline Services & 0.09 & 0.03 & 0.08 & 0.04 & 0.08 & 0.03 & 0.09 & 0.04 \\
\hline Prod / Craft / Repair & 0.16 & 0.14 & 0.17 & 0.20 & 0.21 & 0.21 & 0.20 & 0.11 \\
\hline Operators / Laborers & 0.18 & 0.12 & 0.23 & 0.14 & 0.20 & 0.13 & 0.19 & 0.02 \\
\hline Farm / Forest / Fishery & 0.02 & 0.06 & 0.02 & 0.08 & 0.02 & 0.07 & 0.02 & 0.05 \\
\hline State unemployment rate & 7.42 & 7.83 & 5.55 & 5.52 & 4.40 & 4.31 & 4.71 & 4.81 \\
\hline Expect inheritance & 0.21 & 0.28 & 0.18 & 0.22 & 0.18 & 0.17 & 0.16 & 0.18 \\
\hline Partnership & 0.02 & 0.15 & 0.02 & 0.14 & 0.01 & 0.13 & 0.02 & 0.12 \\
\hline Sole proprietor & 0.06 & 0.49 & 0.06 & 0.41 & 0.04 & 0.43 & 0.05 & 0.42 \\
\hline S corporation & 0.01 & 0.10 & 0.01 & 0.13 & 0.01 & 0.14 & 0.01 & 0.18 \\
\hline Other business type & 0.00 & 0.01 & 0.00 & 0.00 & 0.00 & 0.00 & 0.00 & 0.00 \\
\hline Full-time worker & 0.95 & 0.91 & 0.96 & 0.91 & 0.96 & 0.93 & 0.97 & 0.84 \\
\hline Work 80 hrs + a week & 0.01 & 0.08 & 0.01 & 0.07 & 0.01 & 0.06 & 0.00 & 0.04 \\
\hline Number of Observations & 1146 & 519 & 1283 & 568 & 1209 & 689 & 1210 & 715 \\
\hline
\end{tabular}

Other industries includes transportation, communications, personal services, entertainment, professional services, and public administration

Notes: All estimates are weighted by the sample weights, standard deviations in parentheses, dollar values in 2001 dollars 
Table 5a

Weighted Probit for Self-Employment Choice, TRA86 Sample, 1983, 1989, and 1992 SCF

(for male household heads ages 25-64 who are currently working)

Self-reported self-employment measure

\begin{tabular}{|c|c|c|c|c|}
\hline $\begin{array}{ll}\text { Variables } & \text { Year } \\
\end{array}$ & 1983-1989 & 1983-1989 & 1989-1992 & 1989-1992 \\
\hline Some college $* 1989$ & $\begin{array}{r}0.042 \\
(0.026)\end{array}$ & & & \\
\hline College * 1989 & & $\begin{array}{r}0.023 \\
(0.026)\end{array}$ & & \\
\hline Some college * 1992 & & & $\begin{array}{l}-0.035 \\
(0.026)\end{array}$ & \\
\hline College * 1992 & & & & $\begin{array}{r}0.001 \\
(0.027)\end{array}$ \\
\hline 1989 Year dummy & $\begin{array}{r}0.014 \\
(0.025)\end{array}$ & $\begin{array}{r}0.033 \\
(0.023)\end{array}$ & & \\
\hline 1992 Year dummy & & & $\begin{array}{r}0.024 \\
(0.025)\end{array}$ & $\begin{array}{l}-0.003 \\
(0.022)\end{array}$ \\
\hline Some college or higher & $\begin{array}{r}0.013 \\
(0.018)\end{array}$ & & $\begin{array}{c}0.049 \\
(0.022) * *\end{array}$ & \\
\hline College or higher & & $\begin{array}{r}0.013 \\
(0.020)\end{array}$ & & $\begin{array}{c}0.046 \\
(0.024) *\end{array}$ \\
\hline Tenure & $\begin{array}{r}0.003 \\
(0.002)\end{array}$ & $\begin{array}{r}0.003 \\
(0.002)\end{array}$ & $\begin{array}{c}0.006 \\
(0.002) * * *\end{array}$ & $\begin{array}{c}0.006 \\
(0.002)\end{array}$ *** \\
\hline Tenure squared & $\begin{array}{l}-2.8 \mathrm{E}-05 \\
(6.7 \mathrm{E}-05)\end{array}$ & $\begin{array}{l}-3.5 \mathrm{E}-05 \\
(6.7 \mathrm{E}-05)\end{array}$ & $\begin{array}{l}-6.4 \mathrm{E}-05 \\
(7.1 \mathrm{E}-05)\end{array}$ & $\begin{array}{r}-7.1 \mathrm{E}-05 \\
(7.1 \mathrm{E}-05)\end{array}$ \\
\hline Experience & $\begin{array}{r}0.000 \\
(0.004)\end{array}$ & $\begin{array}{r}0.000 \\
(0.004)\end{array}$ & $\begin{array}{r}0.000 \\
(0.005)\end{array}$ & $\begin{array}{r}0.001 \\
(0.005)\end{array}$ \\
\hline Experience squared & $\begin{array}{r}1.5 \mathrm{E}-05 \\
(6.6 \mathrm{E}-05)\end{array}$ & $\begin{array}{r}-6.3 \mathrm{E}-07 \\
(6.5 \mathrm{E}-05)\end{array}$ & $\begin{array}{r}-1.1 \mathrm{E}-05 \\
(8.8 \mathrm{E}-05)\end{array}$ & $\begin{array}{r}-1.3 \mathrm{E}-05 \\
(8.8 \mathrm{E}-05)\end{array}$ \\
\hline Ag / Mining / Const & $\begin{array}{c}0.202 \\
(0.028)\end{array} * * *$ & $\begin{array}{c}0.198 \\
(0.028) * * *\end{array}$ & $\begin{array}{c}0.211 \\
(0.030) * * *\end{array}$ & $\begin{array}{c}0.217 \\
(0.031) * * *\end{array}$ \\
\hline Manufacturing & $\begin{array}{l}-0.087 \\
(0.013) * * *\end{array}$ & $\begin{array}{c}-0.087 \\
(0.013) * * *\end{array}$ & $\begin{array}{c}-0.094 \\
(0.017) * * *\end{array}$ & $\begin{array}{c}-0.089 \\
(0.017) * * *\end{array}$ \\
\hline Wholesale / Retail & $\begin{array}{c}0.060 \\
(0.022) * * *\end{array}$ & $\begin{array}{c}0.062 \\
(0.022) * * *\end{array}$ & $\begin{array}{c}0.101 \\
(0.027) * * *\end{array}$ & $\begin{array}{c}0.108 \\
(0.027) * * *\end{array}$ \\
\hline FIRE / Bus / Repair & $\begin{array}{c}0.180 \\
(0.031)\end{array} * * *$ & $\begin{array}{c}0.186 \\
(0.031) * * *\end{array}$ & $\begin{array}{c}0.199 \\
(0.032) * * *\end{array}$ & $\begin{array}{l}0.205 \\
(0.032) * * *\end{array}$ \\
\hline Head is white & $\begin{array}{c}0.041 \\
(0.013) * * *\end{array}$ & $\begin{array}{c}0.044 \\
(0.013)\end{array} * * *$ & $\begin{array}{c}0.044 \\
(0.016)\end{array} * * *$ & $\begin{array}{c}0.045 \\
(0.016)\end{array} * * *$ \\
\hline \# of kids under 18 & $\begin{array}{r}0.006 \\
(0.005)\end{array}$ & $\begin{array}{r}0.005 \\
(0.005)\end{array}$ & $\begin{array}{r}0.001 \\
(0.006)\end{array}$ & $\begin{array}{r}0.001 \\
(0.006)\end{array}$ \\
\hline High financial risks & $\begin{array}{c}0.035 \\
(0.016)\end{array}$ ** & $\begin{array}{c}0.037 \\
(0.017)\end{array}$ ** & $\begin{array}{c}0.053 \\
(0.019)\end{array} * * *$ & $\begin{array}{c}0.050 \\
(0.019)\end{array}$ *** \\
\hline Log of house value & $\begin{array}{r}0.002 \\
(0.001)\end{array}$ & $\begin{array}{r}0.002 \\
(0.001)\end{array}$ & $\begin{array}{r}0.002 \\
(0.002)\end{array}$ & $\begin{array}{r}0.001 \\
(0.002)\end{array}$ \\
\hline State unemployment & $\begin{array}{l}-0.001 \\
(0.003)\end{array}$ & $\begin{array}{l}-0.001 \\
(0.003)\end{array}$ & $\begin{array}{c}0.013 \\
(0.005)\end{array}$ ** & $\begin{array}{c}0.013 \\
(0.005)\end{array}$ ** \\
\hline Problem with payments & $\begin{array}{r}0.023 \\
(0.017)\end{array}$ & $\begin{array}{r}0.025 \\
(0.017)\end{array}$ & $\begin{array}{c}0.057 \\
(0.022) * * *\end{array}$ & $\begin{array}{c}0.060 \\
(0.022)\end{array}$ *** \\
\hline Turned down for credit & $\begin{array}{c}0.035 \\
(0.018)\end{array}$ ** & $\begin{array}{c}0.036 \\
(0.018)\end{array}$ ** & $\begin{array}{r}0.022 \\
(0.019)\end{array}$ & $\begin{array}{r}0.024 \\
(0.019)\end{array}$ \\
\hline Expect inheritance & $\begin{array}{r}0.015 \\
(0.015)\end{array}$ & $\begin{array}{r}0.016 \\
(0.015)\end{array}$ & $\begin{array}{r}0.026 \\
(0.018)\end{array}$ & $\begin{array}{r}0.025 \\
(0.018)\end{array}$ \\
\hline Longest prior job SE & $\begin{array}{c}0.069 \\
(0.031)\end{array}$ ** & $\begin{array}{c}0.071 \\
(0.031)\end{array}$ ** & $\begin{array}{c}0.196 \\
(0.041)\end{array} * * *$ & $\begin{array}{c}0.193 \\
(0.041)\end{array}$ *** \\
\hline \# of Observations & 3008 & 3008 & 2973 & 2973 \\
\hline
\end{tabular}

Notes: Coefficient values are marginal effects, standard errors in parentheses,

Regressions are weighted and corrected for multiple imputation

Regressions include controls for cohort group, poor health, marital status, region, and spouse's earnings.

$*$ significant at the $10 \%$ level, ** significant at the $5 \%$ level, *** signficiant at the $1 \%$ level 
Table 5b

Weighted Probit for Self-Employment Choice, OBRA93 Sample,

1992, 1995, 1998, and 2001 SCF

(for male household heads ages 25-64 who are currently working)

Self-reported self-employment measure

\begin{tabular}{|c|c|c|c|c|c|c|}
\hline \begin{tabular}{|ll} 
& Year \\
Variables
\end{tabular} & 1992-1995 & 1992-1995 & 1995-1998 & 1995-1998 & 1998-2001 & 1998-2001 \\
\hline Some college $* 1995$ & $\begin{array}{r}0.005 \\
(0.024)\end{array}$ & & & & & \\
\hline College * 1995 & & $\begin{array}{r}-0.025 \\
(0.021)\end{array}$ & & & & \\
\hline Some college * 1998 & & & $\begin{array}{r}0.028 \\
(0.025)\end{array}$ & & & \\
\hline College * 1998 & & & & $\begin{array}{r}0.020 \\
(0.025)\end{array}$ & & \\
\hline Some college $* 2001$ & & & & & $\begin{array}{r}-0.009 \\
(0.024)\end{array}$ & \\
\hline College $* 2001$ & & & & & & $\begin{array}{r}0.010 \\
(0.024)\end{array}$ \\
\hline 1995 Year dummy & $\begin{array}{r}0.000 \\
(0.022)\end{array}$ & $\begin{array}{r}0.015 \\
(0.019)\end{array}$ & & & & \\
\hline 1998 Year dummy & & & $\begin{array}{r}-0.027 \\
(0.021)\end{array}$ & $\begin{array}{r}-0.010 \\
(0.018)\end{array}$ & & \\
\hline 2001 Year dummy & & & & & $\begin{array}{r}-0.018 \\
(0.020)\end{array}$ & $\begin{array}{r}-0.026 \\
(0.017)\end{array}$ \\
\hline Some college or higher & $\begin{array}{r}0.027 \\
(0.018)\end{array}$ & & $\begin{array}{l}0.062 \\
(0.018) * * *\end{array}$ & & $\begin{array}{c}0.073 \\
(0.018) * * *\end{array}$ & \\
\hline College or higher & & $\begin{array}{c}0.054 \\
(0.020) * * *\end{array}$ & & $\begin{array}{c}0.039 \\
(0.019) * *\end{array}$ & & $\begin{array}{c}0.047 \\
(0.020) * *\end{array}$ \\
\hline Tenure & $\begin{array}{c}0.004 \\
(0.002) * *\end{array}$ & $\begin{array}{c}0.004 \\
(0.002) * *\end{array}$ & $\begin{array}{r}0.003 \\
(0.002)\end{array}$ & $\begin{array}{c}0.003 \\
(0.002) *\end{array}$ & $\begin{array}{c}0.005 \\
(0.002) * * *\end{array}$ & $\begin{array}{c}0.005 \\
(0.002) * * *\end{array}$ \\
\hline Tenure squared & $\begin{array}{r}-8.1 \mathrm{E}-05 \\
(7.2 \mathrm{E}-05)\end{array}$ & $\begin{array}{r}-8.4 \mathrm{E}-05 \\
(7.1 \mathrm{E}-05)\end{array}$ & $\begin{array}{r}-3.2 \mathrm{E}-05 \\
(6.5 \mathrm{E}-05)\end{array}$ & $\begin{array}{l}-3.2 \mathrm{E}-05 \\
(6.5 \mathrm{E}-05)\end{array}$ & $\begin{array}{r}-1.6 \mathrm{E}-05 \\
(5.7 \mathrm{E}-05)\end{array}$ & $\begin{array}{l}-1.5 \mathrm{E}-05 \\
(5.7 \mathrm{E}-05)\end{array}$ \\
\hline Experience & $\begin{array}{c}0.018 \\
(0.004) * * *\end{array}$ & $\begin{array}{c}0.018 \\
(0.004) * * *\end{array}$ & $\begin{array}{c}0.010 \\
(0.005) * *\end{array}$ & $\begin{array}{c}0.008 \\
(0.005) *\end{array}$ & $\begin{array}{r}0.002 \\
(0.005)\end{array}$ & $\begin{array}{r}0.001 \\
(0.005)\end{array}$ \\
\hline Experience squared & $\begin{array}{l}-3.3 \mathrm{E}-04 \\
(9.2 \mathrm{E}-05) * * *\end{array}$ & $\begin{array}{l}-3.4 \mathrm{E}-04 \\
(9.2 \mathrm{E}-05) * * *\end{array}$ & $\begin{array}{r}-9.0 \mathrm{E}-05 \\
(8.6 \mathrm{E}-05)\end{array}$ & $\begin{array}{r}-1.0 \mathrm{E}-04 \\
(8.6 \mathrm{E}-05)\end{array}$ & $\begin{array}{r}2.1 \mathrm{E}-05 \\
(8.2 \mathrm{E}-05)\end{array}$ & $\begin{array}{r}1.3 \mathrm{E}-05 \\
(8.3 \mathrm{E}-05)\end{array}$ \\
\hline Ag / Mining / Const & $\begin{array}{c}0.257 \\
(0.029) * * *\end{array}$ & $\begin{array}{c}0.262 \\
(0.030) * * *\end{array}$ & $\begin{array}{c}0.260 \\
(0.027) * * *\end{array}$ & $\begin{array}{c}0.257 \\
(0.027) * * *\end{array}$ & $\begin{array}{c}0.251 \\
(0.027) * * *\end{array}$ & $\begin{array}{c}0.246 \\
(0.027) * * *\end{array}$ \\
\hline Manufacturing & $\begin{array}{c}-0.027 \\
(0.016) *\end{array}$ & $\begin{array}{r}-0.023 \\
(0.016)\end{array}$ & $\begin{array}{l}-0.058 \\
(0.015) * * *\end{array}$ & $\begin{array}{l}-0.057 \\
(0.015) * * *\end{array}$ & $\begin{array}{l}-0.104 \\
(0.013) * * *\end{array}$ & $\begin{array}{l}-0.105 \\
(0.013) * * *\end{array}$ \\
\hline Wholesale / Retail & $\begin{array}{c}0.075 \\
(0.022) * * *\end{array}$ & $\begin{array}{c}0.079 \\
(0.023) * * *\end{array}$ & $\begin{array}{c}0.079 \\
(0.022) * * *\end{array}$ & $\begin{array}{c}0.078 \\
(0.022) * * *\end{array}$ & $\begin{array}{c}0.052 \\
(0.022) * *\end{array}$ & $\begin{array}{c}0.053 \\
(0.022) * *\end{array}$ \\
\hline FIRE / Bus / Repair & $\begin{array}{c}0.153 \\
(0.027) * * *\end{array}$ & $\begin{array}{c}0.155 \\
(0.027) * * *\end{array}$ & $\begin{array}{c}0.144 \\
(0.025) * * *\end{array}$ & $\begin{array}{c}0.149 \\
(0.026) * * *\end{array}$ & $\begin{array}{c}0.179 \\
(0.024) * * *\end{array}$ & $\begin{array}{c}0.184 \\
(0.024) * * *\end{array}$ \\
\hline Head is white & $\begin{array}{c}0.041 \\
(0.013) * * *\end{array}$ & $\begin{array}{c}0.040 \\
(0.013) * * *\end{array}$ & $\begin{array}{c}0.056 \\
(0.013) * * *\end{array}$ & $\begin{array}{c}0.057 \\
(0.013) * * *\end{array}$ & $\begin{array}{c}0.064 \\
(0.013) * * *\end{array}$ & $\begin{array}{c}0.066 \\
(0.013) * * *\end{array}$ \\
\hline \# of kids under 18 & $\begin{array}{r}-0.007 \\
(0.005)\end{array}$ & $\begin{array}{r}-0.007 \\
(0.005)\end{array}$ & $\begin{array}{r}0.003 \\
(0.006)\end{array}$ & $\begin{array}{r}0.002 \\
(0.006)\end{array}$ & $\begin{array}{r}0.005 \\
(0.006)\end{array}$ & $\begin{array}{r}0.004 \\
(0.006)\end{array}$ \\
\hline High financial risks & $\begin{array}{c}0.039 \\
(0.015) * *\end{array}$ & $\begin{array}{c}0.038 \\
(0.015) * *\end{array}$ & $\begin{array}{r}0.001 \\
(0.013)\end{array}$ & $\begin{array}{r}0.002 \\
(0.013)\end{array}$ & $\begin{array}{r}-0.010 \\
(0.013)\end{array}$ & $\begin{array}{r}-0.010 \\
(0.013)\end{array}$ \\
\hline Log of house value & $\begin{array}{c}0.004 \\
(0.001) * * *\end{array}$ & $\begin{array}{c}0.004 \\
(0.001)\end{array}$ *** & $\begin{array}{r}0.002 \\
(0.001)\end{array}$ & $\begin{array}{c}0.002 \\
(0.001) *\end{array}$ & $\begin{array}{c}0.003 \\
(0.001)\end{array}$ & $\begin{array}{c}0.003 \\
(0.001)\end{array}$ \\
\hline State unemployment & $\begin{array}{c}0.012 \\
(0.005)\end{array} * *$ & $\begin{array}{c}0.012 \\
(0.005) * *\end{array}$ & $\begin{array}{r}-0.006 \\
(0.007)\end{array}$ & $\begin{array}{r}-0.006 \\
(0.007)\end{array}$ & $\begin{array}{r}0.005 \\
(0.008)\end{array}$ & $\begin{array}{r}0.006 \\
(0.008)\end{array}$ \\
\hline Problem with payments & $\begin{array}{r}0.023 \\
(0.017)\end{array}$ & $\begin{array}{r}0.024 \\
(0.017)\end{array}$ & $\begin{array}{r}0.013 \\
(0.016)\end{array}$ & $\begin{array}{r}0.011 \\
(0.016)\end{array}$ & $\begin{array}{r}-0.003 \\
(0.017)\end{array}$ & $\begin{array}{r}-0.001 \\
(0.017)\end{array}$ \\
\hline Turned down for credit & $\begin{array}{r}0.006 \\
(0.014)\end{array}$ & $\begin{array}{r}0.008 \\
(0.014)\end{array}$ & $\begin{array}{r}-0.003 \\
(0.015)\end{array}$ & $\begin{array}{r}0.005 \\
(0.015)\end{array}$ & $\begin{array}{r}-0.010 \\
(0.016)\end{array}$ & $\begin{array}{r}-0.006 \\
(0.016)\end{array}$ \\
\hline Expect inheritance & $\begin{array}{c}0.037 \\
(0.015) * *\end{array}$ & $\begin{array}{c}0.035 \\
(0.015) * *\end{array}$ & $\begin{array}{r}0.003 \\
(0.015)\end{array}$ & $\begin{array}{r}0.002 \\
(0.016)\end{array}$ & $\begin{array}{r}-0.010 \\
(0.015)\end{array}$ & $\begin{array}{r}-0.010 \\
(0.016)\end{array}$ \\
\hline Longest prior job SE & $\begin{array}{c}0.233 \\
(0.042) * * *\end{array}$ & $\begin{array}{c}0.231 \\
(0.042) * * *\end{array}$ & $\begin{array}{c}0.186 \\
(0.040) * * *\end{array}$ & $\begin{array}{c}0.180 \\
(0.040) * * *\end{array}$ & $\begin{array}{c}0.127 \\
(0.036) * * *\end{array}$ & $\begin{array}{c}0.127 \\
(0.036) * * *\end{array}$ \\
\hline \# of Observations & 3517 & 3517 & 3750 & 3750 & 3822 & 3822 \\
\hline
\end{tabular}

Notes: Coefficient values are marginal effects, standard errors in parentheses,

Regressions are weighted and corrected for multiple imputation

Regressions include controls for cohort group, poor health, marital status, region, and spouse's earnings.

* significant at the $10 \%$ level, $* *$ significant at the $5 \%$ level, $* * *$ signficiant at the $1 \%$ level 
Table 6a

Weighted First Stage Regressions for the Marginal or Average Tax Rate, TRA86 Sample,

1983,1989 , and 1992 SCF

(for male household heads ages 25-64 who are currently working)

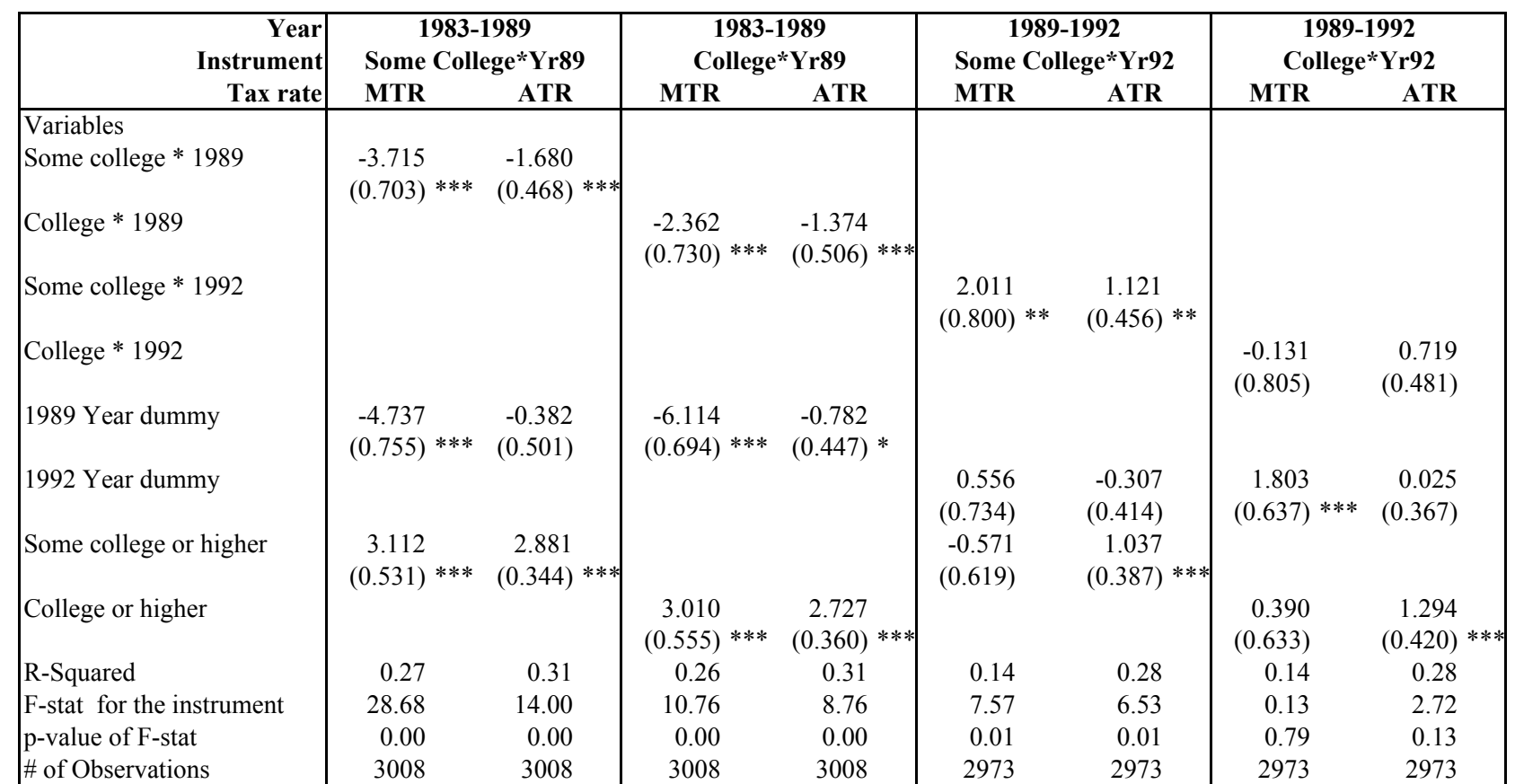

Regressions are weighted and corrected for multiple imputation

Notes: Standard errors in parentheses, * significant at the $10 \%$ level, ** significant at the $5 \%$ level, $* * *$ signficiant at the $1 \%$ level 
Table 6b

Weighted First Stage Regressions for the Marginal or Average Tax Rate, OBRA93 Sample,

1992, 1995, 1998, and 2001 SCF

(for male household heads ages 25-64 who are currently working)

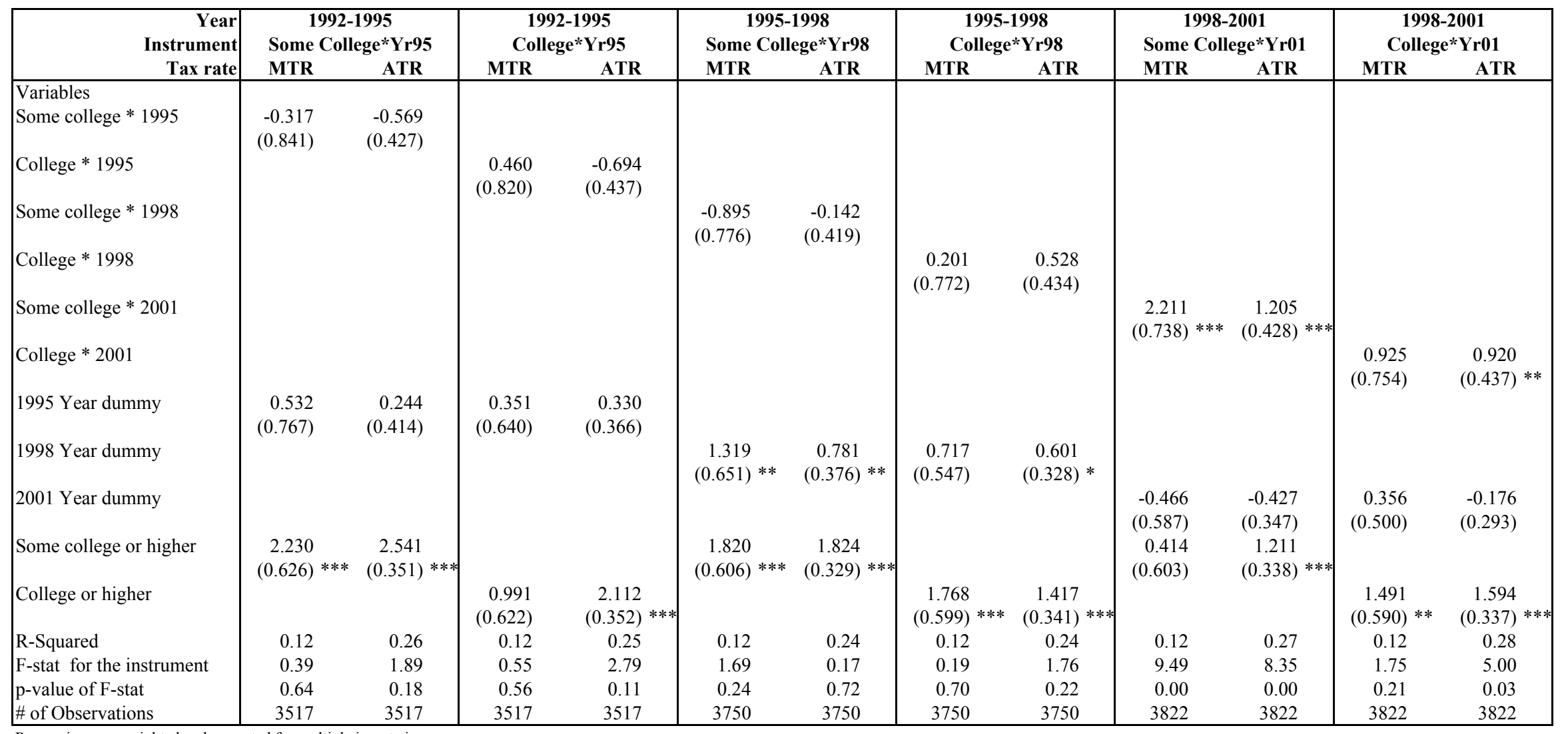

Regressions are weighted and corrected for multiple imputation

Notes: Standard errors in parentheses, * significant at the $10 \%$ level, $* *$ significant at the $5 \%$ level, $* * *$ signficiant at the $1 \%$ level 


\section{Table 7a}

Weighted IV Probit for Self-Employment Choice, TRA86 Sample.

1983,1989 , and 1992 SCF

(for male household heads ages 25-64 who are currently working)

Self-reported self-employment measure

\begin{tabular}{|c|c|c|c|c|c|c|c|c|}
\hline \multirow{2}{*}{$\begin{array}{r}\text { Year } \\
\text { Instrument } \\
\text { Tax rate }\end{array}$} & \multicolumn{2}{|c|}{$\begin{array}{c}1983-1989 \\
\text { Some College*'Yr89 }\end{array}$} & \multicolumn{2}{|c|}{$\begin{array}{c}\text { 1983-1989 } \\
\text { College*Yr89 }\end{array}$} & \multicolumn{2}{|c|}{$\begin{array}{c}1989-1992 \\
\text { Some College*Yr92 }\end{array}$} & \multicolumn{2}{|c|}{$\begin{array}{c}\text { 1989-1992 } \\
\text { College*Yr92 }\end{array}$} \\
\hline & MTR & ATR & MTR & ATR & MTR & ATR & MTR & ATR \\
\hline \begin{tabular}{|l|} 
Variables \\
\end{tabular} & & & & & & & & \\
\hline Total MTR & $\begin{array}{c}-0.010 \\
(0.006)\end{array}$ & & $\begin{array}{r}-0.007 \\
(0.010)\end{array}$ & & $\begin{array}{r}-0.021 \\
(0.016)\end{array}$ & & $\begin{array}{r}-0.020 \\
(0.339)\end{array}$ & \\
\hline Total ATR & & $\begin{array}{r}-0.021 \\
(0.014)\end{array}$ & & $\begin{array}{r}-0.014 \\
(0.017)\end{array}$ & & $\begin{array}{r}-0.034 \\
(0.028)\end{array}$ & & $\begin{array}{r}-0.001 \\
(0.041)\end{array}$ \\
\hline 1989 Year dummy & $\begin{array}{r}-0.039 \\
(0.047)\end{array}$ & $\begin{array}{r}0.008 \\
(0.029)\end{array}$ & $\begin{array}{r}-0.017 \\
(0.071)\end{array}$ & $\begin{array}{r}0.022 \\
(0.031)\end{array}$ & & & & \\
\hline 1992 Year dummy & & & & & $\begin{array}{r}0.041 \\
(0.034)\end{array}$ & $\begin{array}{r}0.017 \\
(0.023)\end{array}$ & $\begin{array}{r}0.036 \\
(0.586)\end{array}$ & $\begin{array}{r}0.002 \\
(0.023)\end{array}$ \\
\hline Some college or higher & $\begin{array}{c}0.048 \\
(0.016)\end{array}$ *** & $\begin{array}{c}0.075 \\
(0.031)\end{array}$ ** & & & $\begin{array}{c}0.042 \\
(0.019)\end{array}$ ** & $\begin{array}{c}0.085 \\
(0.046)\end{array}$ & & \\
\hline College or higher & & & $\begin{array}{c}0.041 \\
(0.024) *\end{array}$ & $\begin{array}{r}0.055 \\
(0.042)\end{array}$ & & & $\begin{array}{r}0.055 \\
(0.115)\end{array}$ & $\begin{array}{r}0.049 \\
(0.075)\end{array}$ \\
\hline Age $45-54$ in 1983 & $\begin{array}{r}-0.045 \\
(0.034)\end{array}$ & $\begin{array}{l}-0.072 \\
(0.038) *\end{array}$ & $\begin{array}{l}-0.044 \\
(0.037)\end{array}$ & $\begin{array}{l}-0.064 \\
(0.044)\end{array}$ & $\begin{array}{r}-0.077 \\
(0.048)\end{array}$ & $\begin{array}{l}-0.125 \\
(0.054) * *\end{array}$ & $\begin{array}{l}-0.079 \\
(0.117)\end{array}$ & $\begin{array}{l}-0.080 \\
(0.083)\end{array}$ \\
\hline Age $35-44$ in 1983 & $\begin{array}{r}-0.064 \\
(0.043)\end{array}$ & $\begin{array}{l}-0.106 \\
(0.051) * *\end{array}$ & $\begin{array}{r}-0.065 \\
(0.047)\end{array}$ & $\begin{array}{r}-0.096 \\
(0.061)\end{array}$ & $\begin{array}{l}-0.120 \\
(0.063) *\end{array}$ & $\begin{array}{l}-0.197 \\
(0.088) * *\end{array}$ & $\begin{array}{r}-0.109 \\
(0.404)\end{array}$ & $\begin{array}{r}-0.100 \\
(0.147)\end{array}$ \\
\hline Age $25-34$ in 1983 & $\begin{array}{r}-0.092 \\
(0.057)\end{array}$ & $\begin{array}{c}-0.162 \\
(0.082) * *\end{array}$ & $\begin{array}{r}-0.094 \\
(0.061)\end{array}$ & $\begin{array}{r}-0.143 \\
(0.097)\end{array}$ & $\begin{array}{l}-0.197 \\
(0.100) * *\end{array}$ & $\begin{array}{c}-0.302 \\
(0.159)\end{array}$ & $\begin{array}{r}-0.178 \\
(1.207)\end{array}$ & $\begin{array}{r}-0.122 \\
(0.233)\end{array}$ \\
\hline Ag / Mining / Const & $\begin{array}{c}0.136 \\
(0.042) * * *\end{array}$ & $\begin{array}{c}0.123 \\
(0.049) * *\end{array}$ & $\begin{array}{c}0.150 \\
(0.060) * *\end{array}$ & $\begin{array}{c}0.145 \\
(0.059) * *\end{array}$ & $\begin{array}{c}0.150 \\
(0.054) * * *\end{array}$ & $\begin{array}{c}0.145 \\
(0.059) * *\end{array}$ & $\begin{array}{r}0.162 \\
(0.867)\end{array}$ & $\begin{array}{c}0.216 \\
(0.084)\end{array}$ ** \\
\hline Manufacturing & $\begin{array}{l}-0.083 \\
(0.013) * * *\end{array}$ & $\begin{array}{l}-0.076 \\
(0.015) * * *\end{array}$ & $\begin{array}{l}-0.083 \\
(0.014) * * *\end{array}$ & $\begin{array}{l}-0.078 \\
(0.017) * * *\end{array}$ & $\begin{array}{l}-0.090 \\
(0.018) * * *\end{array}$ & $\begin{array}{c}-0.087 \\
(0.020)\end{array} * * *$ & $\begin{array}{r}-0.086 \\
(0.113)\end{array}$ & $\begin{array}{l}-0.092 \\
(0.023) * * *\end{array}$ \\
\hline Wholesale / Retail & $\begin{array}{c}0.042 \\
(0.021) * *\end{array}$ & $\begin{array}{r}0.029 \\
(0.025)\end{array}$ & $\begin{array}{c}0.050 \\
(0.022) * *\end{array}$ & $\begin{array}{c}0.044 \\
(0.025) *\end{array}$ & $\begin{array}{c}0.081 \\
(0.029) * * *\end{array}$ & $\begin{array}{c}0.066 \\
(0.037) *\end{array}$ & $\begin{array}{r}0.089 \\
(0.206)\end{array}$ & $\begin{array}{c}0.103 \\
(0.041)\end{array}$ ** \\
\hline FIRE / Bus / Repair & $\begin{array}{c}0.155 \\
(0.032) * * *\end{array}$ & $\begin{array}{c}0.145 \\
(0.036)\end{array} * * *$ & $\begin{array}{c}0.168 \\
(0.033) * * *\end{array}$ & $\begin{array}{c}0.165 \\
(0.035) * * *\end{array}$ & $\begin{array}{c}0.189 \\
(0.038) * * *\end{array}$ & $\begin{array}{c}0.194 \\
(0.039) * * *\end{array}$ & $\begin{array}{r}0.209 \\
(0.136)\end{array}$ & $\begin{array}{c}0.204 \\
(0.034)\end{array}$ *** \\
\hline Head is white & $\begin{array}{c}0.039 \\
(0.013) * * *\end{array}$ & $\begin{array}{c}0.049 \\
(0.014) * * *\end{array}$ & $\begin{array}{c}0.042 \\
(0.013) * * *\end{array}$ & $\begin{array}{c}0.049 \\
(0.015) * * *\end{array}$ & $\begin{array}{c}0.037 \\
(0.018) * *\end{array}$ & $\begin{array}{c}0.061 \\
(0.022) * * *\end{array}$ & $\begin{array}{r}0.041 \\
(0.124)\end{array}$ & $\begin{array}{r}0.044 \\
(0.028)\end{array}$ \\
\hline High financial risks & $\begin{array}{c}0.036 \\
(0.017) * *\end{array}$ & $\begin{array}{c}0.035 \\
(0.018) * *\end{array}$ & $\begin{array}{c}0.037 \\
(0.017) * *\end{array}$ & $\begin{array}{c}0.037 \\
(0.018) * *\end{array}$ & $\begin{array}{c}0.041 \\
(0.022) *\end{array}$ & $\begin{array}{c}0.087 \\
(0.042) * *\end{array}$ & $\begin{array}{r}0.042 \\
(0.102)\end{array}$ & $\begin{array}{r}0.048 \\
(0.049)\end{array}$ \\
\hline Log of house value & $\begin{array}{c}0.003 \\
(0.002) * *\end{array}$ & $\begin{array}{c}0.004 \\
(0.002) *\end{array}$ & $\begin{array}{r}0.003 \\
(0.002)\end{array}$ & $\begin{array}{r}0.003 \\
(0.002)\end{array}$ & $\begin{array}{c}0.004 \\
(0.003)\end{array}$ & $\begin{array}{r}0.005 \\
(0.003)\end{array}$ & $\begin{array}{r}0.004 \\
(0.044)\end{array}$ & $\begin{array}{r}0.001 \\
(0.005)\end{array}$ \\
\hline State unemployment & $\begin{array}{r}-0.003 \\
(0.004)\end{array}$ & $\begin{array}{l}-0.002 \\
(0.004)\end{array}$ & $\begin{array}{r}-0.002 \\
(0.004)\end{array}$ & $\begin{array}{r}-0.002 \\
(0.004)\end{array}$ & $\begin{array}{c}0.010 \\
(0.006)\end{array}$ & $\begin{array}{c}0.017 \\
(0.007) * *\end{array}$ & $\begin{array}{r}0.010 \\
(0.035)\end{array}$ & $\begin{array}{r}0.012 \\
(0.009)\end{array}$ \\
\hline Longest prior job SE & $\begin{array}{c}0.053 \\
(0.031) *\end{array}$ & $\begin{array}{c}0.056 \\
(0.033) *\end{array}$ & $\begin{array}{c}0.059 \\
(0.033) *\end{array}$ & $\begin{array}{c}0.063 \\
(0.033) *\end{array}$ & $\begin{array}{c}0.156 \\
(0.048) * * *\end{array}$ & $\begin{array}{c}0.198 \\
(0.053) * * *\end{array}$ & $\begin{array}{r}0.163 \\
(0.465)\end{array}$ & $\begin{array}{c}0.189 \\
(0.045)\end{array}$ *** \\
\hline \# of Observations & 3008 & 3008 & 3008 & 3008 & 2973 & 2973 & 2973 & 2973 \\
\hline
\end{tabular}

Regressions are weighted and corrected for multiple imputation

Regressions include controls for tenure at the current job, labor force experience, poor health, marital status, number of children under 18, region,

spouse's earnings, credit worthiness, and expectation of inheritance

Notes: Coefficient values are marginal effects, standard errors in parentheses, ${ }^{*}$ significant at the $10 \%$ level, $* *$ significant at the $5 \%$ level, $* * *$ signficiant at the $1 \%$ level 
Table $7 \mathrm{~b}$

Weighted IV Probit for Self-Employment Choice, OBRA93 Sample,

1992, 1995, 1998, and 2001 SCF

(for male household heads ages 25-64 who are currently working)

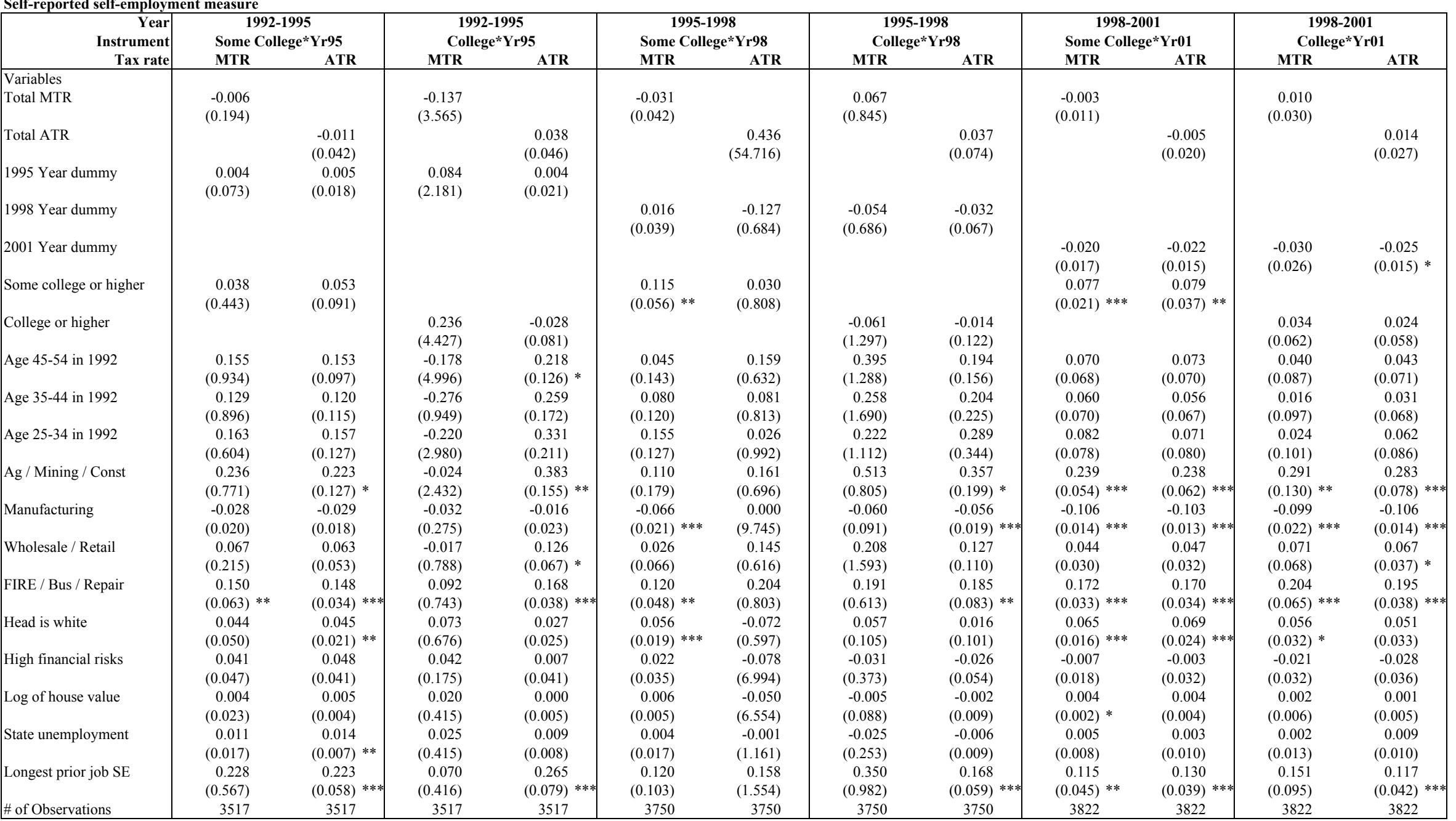

\section{egressions are weighted and corrected for multiple imputat in}

Regressions include controls for tenure at the current job, labor force experience, poor health, marital status, number of children under 18 , region,

spouse's earnings, credit worthiness, and expectation of inheritance

Notes: Coefficient values are marginal effects, standard errors in parentheses, * significant at the $10 \%$ level, $* *$ significant at the $5 \%$ level, $* * *$ signficiant at the $1 \%$ level 


\section{Table A1}

Comparison of CPS and SCF Self-Employment Rates

(for male household heads ages 25-64 who are currently working)

\begin{tabular}{|c|c|c|c|c|c|c|c|}
\hline \multirow[b]{2}{*}{ Year } & \multicolumn{3}{|c|}{ TRA86 Sample } & \multicolumn{4}{|c|}{ OBRA93 Sample } \\
\hline & 1983 & 1989 & 1992 & 1992 & 1995 & 1998 & 2001 \\
\hline $\begin{array}{l}\text { SCF } \\
\text { C-Corporations excluded } \\
\text { Self-reported SE }\end{array}$ & 11.4 & 16.6 & 18.6 & 15.1 & 14.5 & 17.0 & 17.7 \\
\hline $\begin{array}{l}\text { Self-reported SE and } \\
\text { has an active business }\end{array}$ & 7.4 & 11.6 & 14.1 & 11.2 & 9.8 & 12.1 & 12.7 \\
\hline $\begin{array}{l}\text { C-Corporations included } \\
\text { Self-reported SE }\end{array}$ & 13.7 & 18.3 & 20.6 & 16.6 & 15.4 & 18.8 & 19.6 \\
\hline $\begin{array}{l}\text { Self-reported SE and } \\
\text { has an active business }\end{array}$ & 9.8 & 13.3 & 16.2 & 12.8 & 10.8 & 13.9 & 14.7 \\
\hline $\begin{array}{l}\text { CPS ORG } \\
\text { Self-employed }\end{array}$ & 17.0 & 18.5 & 19.7 & 16.1 & 16.1 & 16.4 & 16.6 \\
\hline Self-employed, unincorporated & 12.0 & 12.6 & 13.5 & 11.2 & 10.7 & 10.7 & 10.7 \\
\hline Self-employed, incorporated & 5.0 & 5.9 & 6.2 & 4.9 & 5.4 & 5.7 & 6.0 \\
\hline
\end{tabular}

Notes: All estimated weighted by sample weights. 
Table A2

Medians of Various Characteristics for the TRA86 Sample, 1983, 1989, and 1992 SCF

(for male household heads ages 25-64 who are currently working)

Self-reported self-employment measure

\begin{tabular}{|l|cc|cc|cc|}
\hline & \multicolumn{7}{c|}{ TRA86 Sample } \\
\cline { 2 - 7 } & \multicolumn{2}{|c}{ Year } & \multicolumn{2}{c|}{$\mathbf{1 9 8 9}$} & \multicolumn{2}{c|}{$\mathbf{1 9 9 2}$} \\
\hline Variable & Emp & SE & Emp & SE & Emp & SE \\
\hline Total MTR & 42.9 & 38.4 & 35.5 & 33.0 & 36.6 & 36.3 \\
Total ATR & 30.3 & 24.8 & 29.0 & 26.8 & 29.3 & 29.4 \\
Head's earnings & 36,504 & 37,180 & 41,400 & 36,000 & 38,688 & 37,200 \\
Spouse / partner's earnings & 4,056 & 0 & 9,660 & 4,320 & 8,060 & 5,545 \\
HH income & 51,920 & 52,800 & 57,600 & 63,360 & 54,610 & 62,230 \\
HH net worth & 64,075 & 151,340 & 98,504 & 282,900 & 88,449 & 214,024 \\
Value of active business(es) & 0 & 24,917 & 0 & 13,000 & 0 & 25,001 \\
Value of primary residence & 67,600 & 92,950 & 82,800 & 103,500 & 86,800 & 111,600 \\
Head's tenure at current job & 7 & 7 & 9 & 10 & 8 & 10 \\
Head's experience & 18 & 22 & 21 & 24 & 25 & 25 \\
Head's weekly hours & 40 & 50 & 40 & 50 & 40 & 50 \\
Head's weeks per year & 52 & 52 & 52 & 52 & 52 & 52 \\
Head's age & 38 & 41 & 41 & 44 & 44 & 45 \\
\hline
\end{tabular}


Medians of Various Characteristics for the OBRA93 Sample, 1992, 1995, 1998, and 2001 SCF

(for male household heads ages 25-64 who are currently working)

Self-reported self-employment measure

\begin{tabular}{|c|c|c|c|c|c|c|c|c|}
\hline \multirow{2}{*}{\begin{tabular}{|l|} 
\\
Variable \\
Year \\
\end{tabular}} & \multicolumn{6}{|c|}{ OBRA93 Sample } & \multirow{2}{*}{\multicolumn{2}{|c|}{2001}} \\
\hline & \multicolumn{2}{|c|}{1992} & \multicolumn{2}{|c|}{1995} & \multicolumn{2}{|c|}{1998} & & \\
\hline Total MTR & 36.3 & 35.6 & 36.3 & 34.3 & 37.1 & 35.8 & 41.0 & 39.8 \\
\hline Head's earnings & 36,109 & 34,290 & 38,870 & 35,400 & 41,040 & 38,500 & 43,000 & 35,000 \\
\hline Spouse / partner's earnings & 8,928 & 2,480 & 9,529 & 5,664 & 8,030 & 14,040 & 14,411 & 8,406 \\
\hline $\mathrm{HH}$ income & 49,530 & 57,150 & 53,100 & 48,380 & 57,200 & 63,800 & 64,890 & 77,250 \\
\hline Value of primary residence & 64,480 & 109,120 & 82,800 & 86,250 & 92,880 & 125,280 & 101,000 & 180,000 \\
\hline Head's tenure at current job & 6 & 8 & 6 & 8 & 8 & 10 & 8 & 15 \\
\hline Head's experience & 18 & 20 & 21 & 24 & 23 & 26 & 26 & 29 \\
\hline Head's weekly hours & 40 & 50 & 40 & 50 & 40 & 50 & 40 & 48 \\
\hline Head's weeks per year & 52 & 52 & 52 & 52 & 52 & 52 & 52 & 52 \\
\hline
\end{tabular}

Notes: All estimates are weighted by the sample weights, standard deviations in parentheses, dollar values in 2001 dollars 